\title{
Role of Vacha (Acorus calamus Linn.) in Neurological and Metabolic Disorders: Evidence from Ethnopharmacology, Phytochemistry, Pharmacology and Clinical Study
}

\author{
Vineet Sharma ${ }^{1}{ }^{(}$, Rohit Sharma ${ }^{1, *(\mathbb{D})}$, DevNath Singh Gautam ${ }^{1}\left(\mathbb{D}\right.$, Kamil Kuca $^{2}, * \mathbb{(}$, \\ Eugenie Nepovimova ${ }^{2}$ and Natália Martins ${ }^{3,4, *}$ (D) \\ 1 Department of Rasa Shastra and Bhaishajya Kalpana, Faculty of Ayurveda, Institute of Medical Sciences, \\ BHU, Varanasi, Uttar Pradesh 221005, India; vinitbhu93@gmail.com (V.S.); drdnsgautam@gmail.com (D.S.G.) \\ 2 Department of Chemistry, Faculty of Science, University of Hradec Králové, Rokitanskeho 62, \\ 50003 Hradec Králové, Czech Republic; eugenie.nepovimova@uhk.cz \\ 3 Faculty of Medicine, University of Porto, Alameda Prof. Hernani Monteiro, 4200-319 Porto, Portugal \\ 4 Institute for research and Innovation in Heath (i3S), University of Porto, Rua Alfredo Allen, \\ 4200-135 Porto, Portugal \\ * Correspondence: rohitsharma@bhu.ac.in or dhanvantari86@gmail.com (R.S.); kamil.kuca@uhk.cz (K.K.); \\ ncmartins@med.up.pt (N.M.)
}

Received: 23 March 2020; Accepted: 14 April 2020; Published: 19 April 2020

\begin{abstract}
Vacha (Acorus calamus Linn. (Acoraceae)) is a traditional Indian medicinal herb, which is practiced to treat a wide range of health ailments, including neurological, gastrointestinal, respiratory, metabolic, kidney, and liver disorders. The purpose of this paper is to provide a comprehensive up-to-date report on its ethnomedicinal use, phytochemistry, and pharmacotherapeutic potential, while identifying potential areas for further research. To date, 145 constituents have been isolated from this herb and identified, including phenylpropanoids, sesquiterpenoids, and monoterpenes. Compelling evidence is suggestive of the biopotential of its various extracts and active constituents in several metabolic and neurological disorders, such as anticonvulsant, antidepressant, antihypertensive, anti-inflammatory, immunomodulatory, neuroprotective, cardioprotective, and anti-obesity effects. The present extensive literature survey is expected to provide insights into the involvement of several signaling pathways and oxidative mechanisms that can mitigate oxidative stress, and other indirect mechanisms modulated by active biomolecules of $A$. calamus to improve neurological and metabolic disorders.
\end{abstract}

Keywords: Acorus calamus; ethnomedicinal; phytochemistry; toxicity; pharmacological action; clinical trial; neuroprotective; neurological; metabolic application

\section{Introduction}

Globally, an estimated 450 million people are suffering from mental disorders and about 425 million are known diabetics [1,2]. In 2016, 650 million adults were obese and about 23.6 million people were estimated to die of cardiovascular diseases (CVDs) by the year 2030 [3]. Metabolic disorders are characterized by hypertension, hyperglycemia, abdominal obesity, and hyperlipidemia, which may worsen the neurological disease risk. Improper diet (high calorie intake), lifestyle (e.g., smoking, chronic alcohol consumption, sedentary habits), and/or low level of nitrosamines (through processed food, tobacco smoke, and nitrate-containing fertilizers) affect the liver and can further lead to fatty liver disease $[4,5]$. In this condition, fatty changes may be due to increased production or decreased use of fatty 
acids, which may lead to inflammatory injury of hepatocytes, where inflammatory mediators, such as cytokines and interleukins, are released, which, along with lower adipokines, may eventually develop hepatic insulin resistance [6]. The same pathology also mediates diabetes, obesity, and peripheral insulin resistance. Insulin resistance also promotes the release of ceramides and other toxic lipids which enter the circulation and cross the blood-brain barrier leading to brain insulin resistance, inflammatory changes, and further progression to neurodegeneration and neurological disorders (Figure 1) [7].

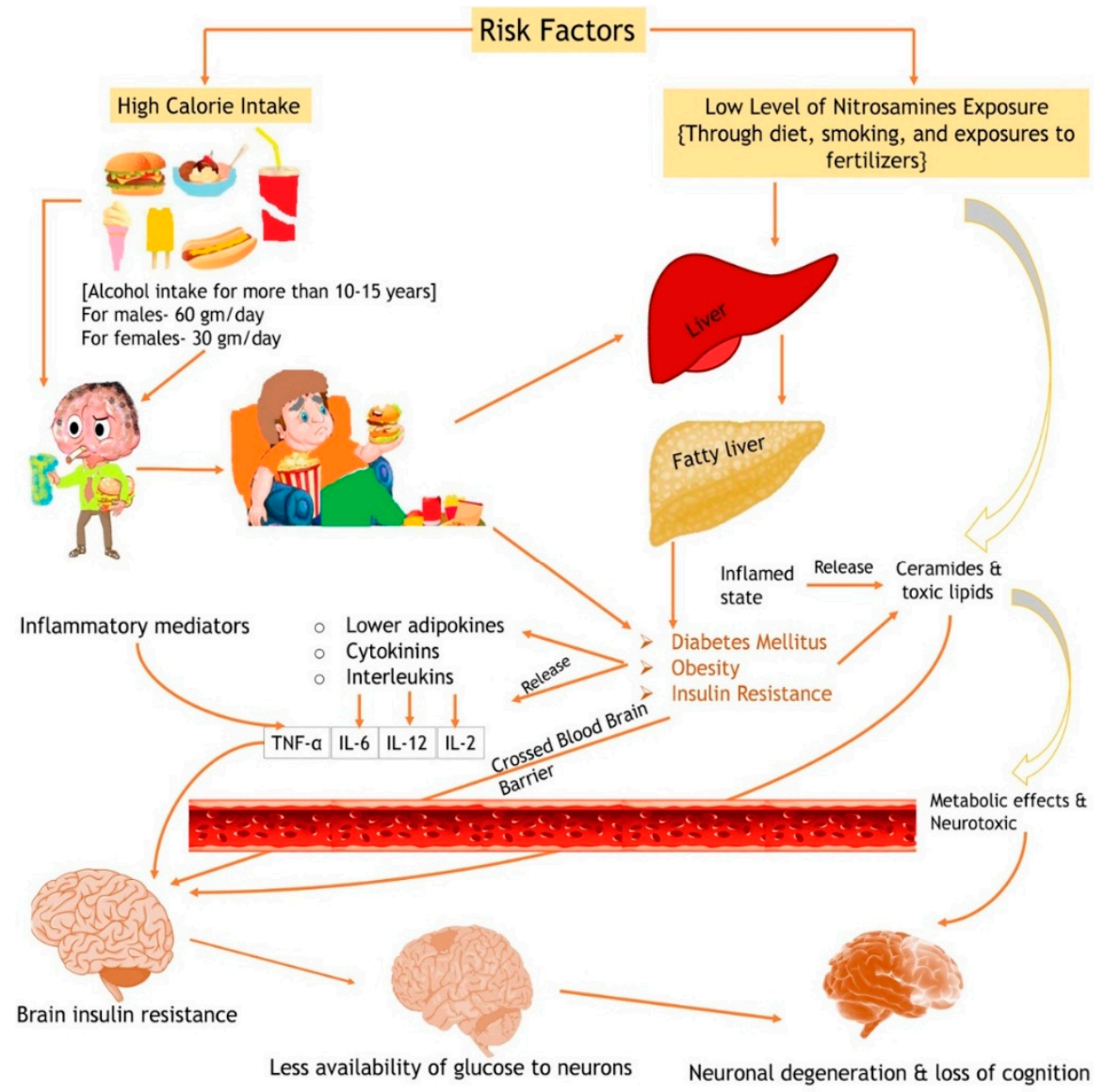

Figure 1. Pathophysiology of insulin resistance, metabolic malfunction, and progression to a neurological disorder. TNF, tumor necrosis factor; IL, interleukin.

Acorus calamus Linn. (Acoraceae), also known as Vacha in Sanskrit, is a mid-term, perennial, fragrant herb which is practiced in the Ayurvedic (Indian traditional) and the Chinese system of medicine. The plant's rhizomes are brown in color, twisted, cylindrical, curved, and shortly nodded. The leaves are radiant green, with a sword-like structure, which is thicker in the middle and has curvy margins (Figure 2) [8]. Several reports ascertained a wide range of biological activities involving its myriad of active phytoconstituents. In this sense, the intent of this review is to assemble and summarize the geographical distribution, ethnopharmacology, phytochemistry, mechanism of action of $A$. calamus along with preclinical and clinical claims that are relevant to manage neurological and metabolic disorders. To the best of our knowledge, so far, none of the published reviews has described all the characteristics of this medicinal plant [9-11]. The present report is expected to produce a better understanding of the characteristics, bioactivities, and mechanistic aspects of this plant and to provide new leads for future research. 


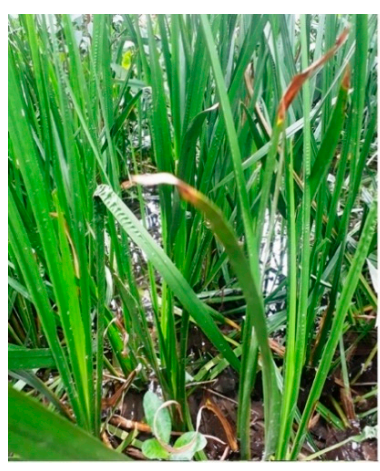

(A)

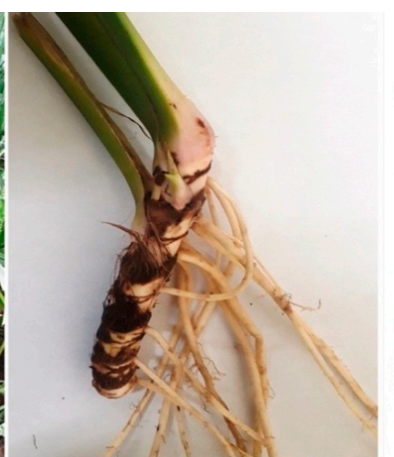

(B)

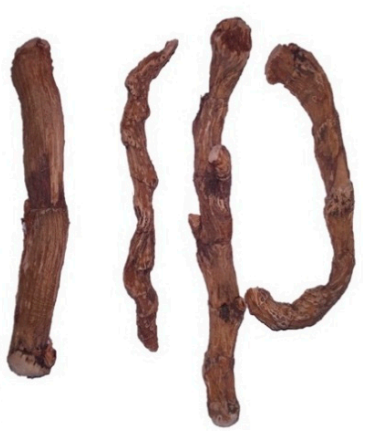

(C)

Figure 2. Photographs of Acorus calamus: (A) Natural habitat; (B) Fresh rhizome; (C) Dried rhizome.

\section{Methodology}

The literature available in the Ayurvedic classical texts, technical reports, online scientific records such as SciFinder, Google Scholar, MEDLINE, EMBASE, Scopus directory were explored for ethnomedicinal uses, geographical distribution, phytochemistry, pharmacology, and biomedicine by applying the following keywords: "Acorus calamus", "Vacha", "Medhya", "neuroprotective", "phytochemistry", "obesity", "oxidative stress", "anticonvulsant", "antidepressant", "antihypertensive", "anti-inflammatory", "immunomodulator", "antioxidant", "diabetes", "mechanism of action" with their corresponding medical subject headings (MeSH) terms using conjunctions OR/AND. The search was focused on identifying Ayurvedic claims in the available ethnomedicinal, phytochemical, preclinical, clinical, and toxicity reports to understand the role of $A$. calamus in neurological and metabolic disorders. This search was undertaken between January 2018 and January 2020. Searches were restricted to the English language. The search methodology as per the Preferred Reporting Items for Systematic Reviews and Meta-Analysis (PRISMA) is stipulated in the flowchart in Figure 3.

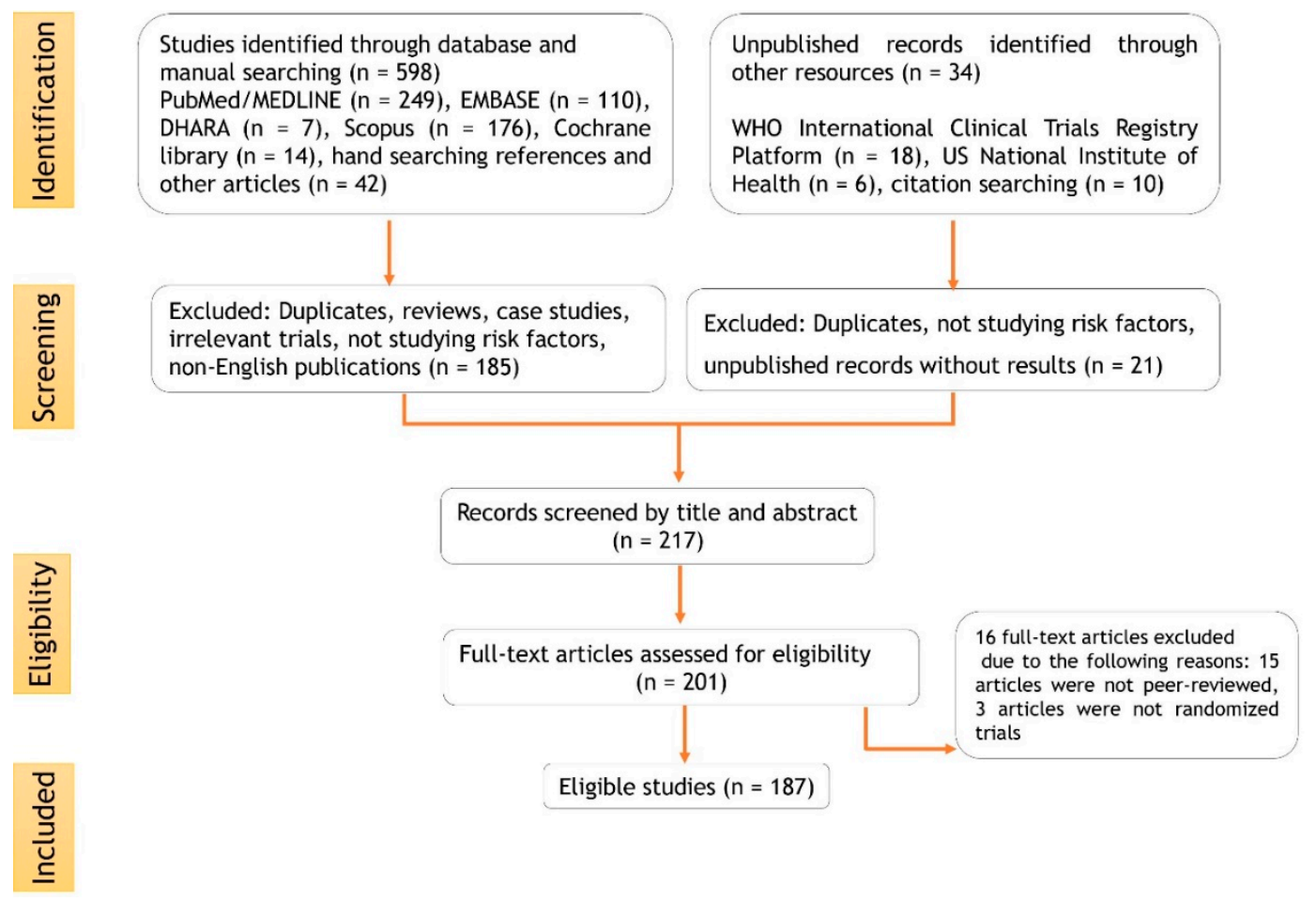

Figure 3. Flowchart of the selection process. 


\section{Geographical Distribution}

A. calamus grows in high $(1800 \mathrm{~m})$ and low $(900 \mathrm{~m})$ altitudes and it is found to be geographically available in 42 countries [8]. Furthermore, as per the Global Biodiversity Information Facility records [12], the distribution of this plant in several parts of the world, as well as in India, is highlighted in Figure 4.

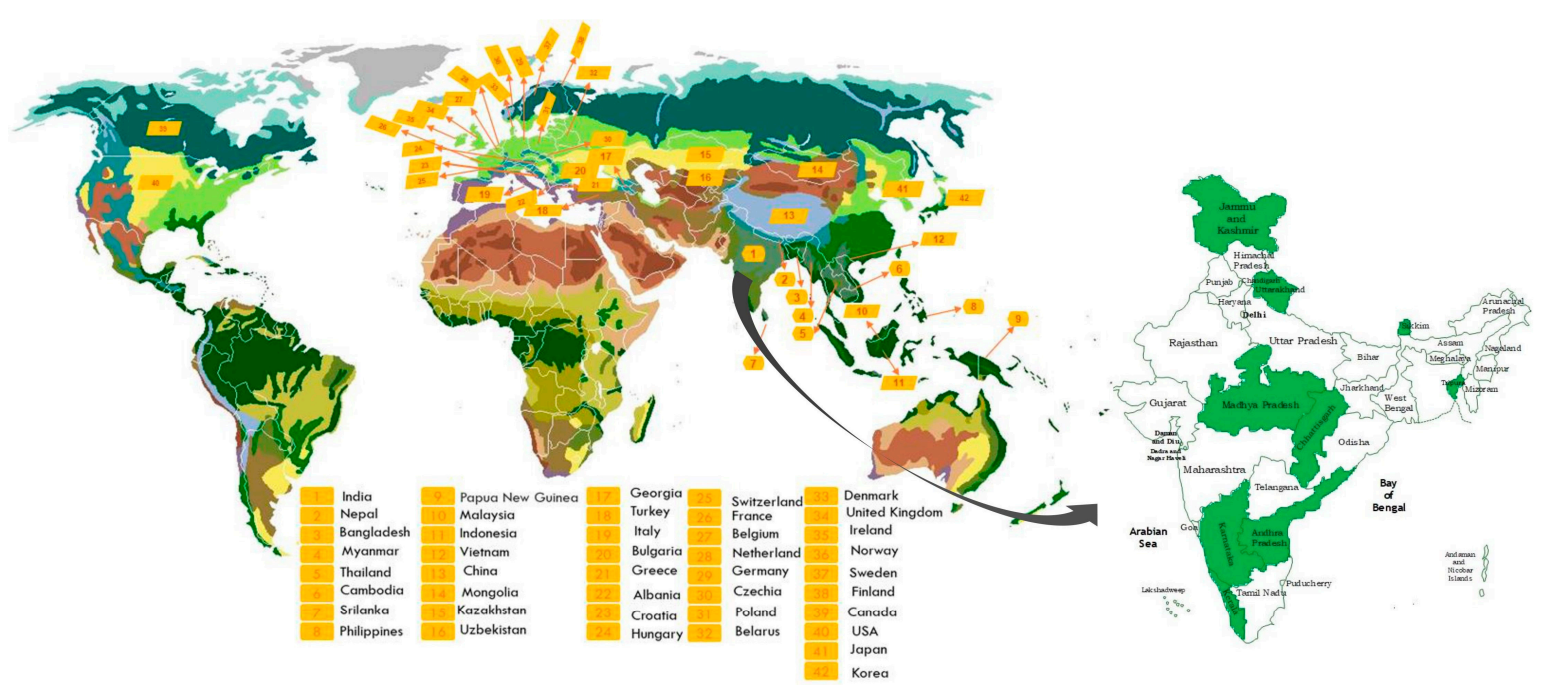

Figure 4. Distribution of A. calamus worldwide and in India.

\section{Ethnomedicinal Use}

This plant is being practiced traditionally in the Indian Ayurvedic tradition, as well as in the Chinese system of medicine for analgesic, antipyretic, tonic, anti-obesity, and healing purposes; it is highly effective for skin diseases, along with neurological, gastrointestinal, respiratory, and several other health disorders. Rhizomes and leaves are found to be profusely practiced in the form of infusion, powder, paste, or decoction [13-72]. The ethnomedicinal uses of the A. calamus are detailed in Table 1.

A. calamus rhizomes and leaves are also used as an active pharmaceutical ingredient in various Ayurvedic formulations (Table 2). 
Table 1. Ethnomedicinal use of A. calamus in various countries.

\begin{tabular}{|c|c|c|c|c|}
\hline Country & Ailment/Use & Part Used/ Dosage Form & Route of Administration & References \\
\hline \multirow{16}{*}{ India } & Eczema & $\begin{array}{l}\text { The paste of } A \text {. calamus rhizomes are given with the paste of } \\
\text { Curcuma aromatica rhizomes and Azadirachta indica leaves }\end{array}$ & \multirow{11}{*}{ Oral } & \multirow{2}{*}{ [13] } \\
\hline & Skin diseases & $\begin{array}{c}\text { Rhizomes paste A. calamus and C. aromatica are applied with the } \\
\text { seed paste of Argemone Mexicana }\end{array}$ & & \\
\hline & $\begin{array}{l}\text { Cough, stuttering, ulcer, fever, } \\
\text { dermatitis, scab, sores }\end{array}$ & Rhizomes & & {$[14]$} \\
\hline & \multirow[b]{2}{*}{ Cold, cough, and fever } & $\begin{array}{l}\text { Rhizomes paste of A. calamus is given to children with mother's } \\
\text { milk, Myristica fragrance, and Calunarejan spinosa fruits }\end{array}$ & & [15] \\
\hline & & $\begin{array}{l}\text { Two teaspoonfuls of herbal powder containing A. calamus } \\
\text { rhizomes, Boerhaavia diffusa roots, Calonyction muricutum flower } \\
\text { pedicles, Ipomoea muricate seeds, Senna leaves, Cassia fistula fruits } \\
\text { pulp, Curcuma longa rhizomes, Helicteres isora fruits, and Mentha } \\
\text { arvensis leaves, black pepper is taken with lukewarm water }\end{array}$ & & [16] \\
\hline & Gastric disorders & A. calamus rhizomes paste is given with cow milk & & [17] \\
\hline & $\begin{array}{l}\text { Carminative, flavoring, tonic, } \\
\text { and head lice infestation }\end{array}$ & $\begin{array}{l}\text { Infusion of a dried rhizomes (collected and stored in the } \\
\text { autumn season) }\end{array}$ & & [17-19] \\
\hline & $\begin{array}{c}\text { Epilepsy, dysentery, mental } \\
\text { illnesses, diarrhea, kidney and } \\
\text { liver disorders }\end{array}$ & A. calamus rhizomes paste is given with honey & & {$[20]$} \\
\hline & Wounds, fever, body pain & Rhizomes & & {$[21,22]$} \\
\hline & Dysentery & $\begin{array}{l}\text { Fresh ground rhizomes is mixed with hot water } \\
\text { and given for } 3 \text { days }\end{array}$ & & [23] \\
\hline & Stimulant & Dry powder of $A$. calamus is given with honey & & [24] \\
\hline & Injuries & External application of the $A$. calamus rhizomes paste & \multirow{5}{*}{ Dermal } & [25] \\
\hline & Stomachache & Ash of the A. calamus rhizomes paste & & [26] \\
\hline & Otitis externa & A. calamus roots paste is given with coconut husk juice & & [27] \\
\hline & Lotion & Fresh leaves of $A$. calamus & & [28] \\
\hline & Cough, cancer, and fever & $\begin{array}{l}\text { A. calamus roots juice is given with honey and } \\
\text { MyristicaDactyloides }\end{array}$ & & [29] \\
\hline
\end{tabular}


Table 1. Cont.

\begin{tabular}{|c|c|c|c|c|}
\hline Country & Ailment/Use & Part Used/ Dosage Form & Route of Administration & References \\
\hline & Analgesic & A. calamus rhizomes are given with cinchona bark & \multirow{14}{*}{ Oral } & \multirow{4}{*}[30]{} \\
\hline & $\begin{array}{l}\text { Gastrointestinal, respiratory, } \\
\text { emmenagogue, antihelmintic }\end{array}$ & Rhizomes & & \\
\hline & Prolonged labor & Rhizomes is applied with saffron and horse milk & & \\
\hline & Paralysis, arthritis & Rhizomes ash is applied with castor oil & & \\
\hline & $\begin{array}{l}\text { Neurological disorder, } \\
\text { gastrointestinal, respiratory, } \\
\text { increases menstrual flow, } \\
\text { analgesic, contraceptive }\end{array}$ & \multirow{2}{*}{ Rhizomes } & & [31-33] \\
\hline & $\begin{array}{l}\text { Herpangina, analgesic, } \\
\text { neurological disorder, } \\
\text { gastrointestinal, respiratory }\end{array}$ & & & [34] \\
\hline Pakistan & Colic and diarrhea & Whole plant & & [35] \\
\hline \multirow{4}{*}{ Nepal } & Blood pressure & Roots infusion of $A$. calamus & & [36] \\
\hline & $\begin{array}{l}\text { Cough, headache, snake bite, } \\
\text { sore throat, and pain }\end{array}$ & Rhizomes & & \multirow{2}{*}{ [37] } \\
\hline & Dysentery & Rhizomes juice is given with hot water & & \\
\hline & Neurological, respiratory & Rhizomes & & {$[38]$} \\
\hline Malaysia & $\begin{array}{l}\text { Rheumatism, diarrhea, } \\
\text { dyspepsia, and hair loss }\end{array}$ & Whole plant & & [39] \\
\hline \multirow[t]{2}{*}{ Tibet } & Fever, gastrointestinal & $\begin{array}{c}\text { Dried rhizomes is given with Saussurea lappa, Ferula foetida, } \\
\text { Terminalia chebula, Cuminum cyminum, Inula racemosa, } \\
\text { and Zingiber officinale }\end{array}$ & & [40] \\
\hline & Cancer & Rhizomes & & [41] \\
\hline
\end{tabular}


Table 1. Cont.

\begin{tabular}{|c|c|c|c|c|}
\hline Country & Ailment/Use & Part Used/ Dosage Form & Route of Administration & References \\
\hline \multirow{8}{*}{ China } & $\begin{array}{c}\text { Gastrointestinal, respiratory, } \\
\text { neuroprotective, analgesic, } \\
\text { contraceptive, cancer }\end{array}$ & Rhizomes & & [42-44] \\
\hline & $\begin{array}{l}\text { Antipyretic and } \\
\text { ear-related disease }\end{array}$ & $\begin{array}{l}\text { Rhizomes given with squeezed Coccinia cordifolia stems along } \\
\text { with water }\end{array}$ & & \multirow{3}{*}{ [45] } \\
\hline & Detoxification & Rhizomes with vinegar, Alpinia galanga, Zingiber purpureum & & \\
\hline & Analgesic & Herbal baths of the rhizome & \multirow{2}{*}{ External } & \\
\hline & Hemorrhage & Rhizomes paste & & [46] \\
\hline & Aphrodisiac & Rhizomes & \multirow{2}{*}{ Oral } & [47] \\
\hline & Hallucination & $\begin{array}{l}\text { Rhizomesare mixed with Indian hemp and } \\
\text { Podophyllum pleianthum }\end{array}$ & & {$[48]$} \\
\hline & Fair skin & Leaves of $A$. calamus are given with Artemisia vulgaris & Dermal & [49] \\
\hline Indonesia & \multirow{2}{*}{ Gastrointestinal } & Rhizomes & \multirow{10}{*}{ Oral } & {$[50]$} \\
\hline \multirow{4}{*}{ England } & & Rhizomes blended with chalk and magnesium oxide & & {$[51]$} \\
\hline & $\begin{array}{c}\text { Gastrointestinal, antibacterial, } \\
\text { analgesic }\end{array}$ & Rhizomes & & \multirow{2}{*}{ [52] } \\
\hline & $\begin{array}{l}\text { Neurological, dysentery, and } \\
\text { chronic catarrh }\end{array}$ & Rhizomesare given with Gentiana campestris L. & & \\
\hline & Malaria & \multirow{6}{*}{ Rhizomes } & & [53] \\
\hline Europe & $\begin{array}{l}\text { Obesity, influenza, } \\
\text { gastrointestinal, respiratory }\end{array}$ & & & {$[54,55]$} \\
\hline $\begin{array}{l}\text { Republic of } \\
\text { South Africa }\end{array}$ & $\begin{array}{l}\text { Tooth powder, gastrointestinal, } \\
\text { tonic, aphrodisiac }\end{array}$ & & & [56] \\
\hline Sweden & Liquor & & & [57] \\
\hline Germany & $\begin{array}{l}\text { Increases menstrual flow, } \\
\text { gastrointestinal }\end{array}$ & & & {$[58,59]$} \\
\hline Java & Lactation & & & [60] \\
\hline
\end{tabular}


Table 1. Cont.

\begin{tabular}{|c|c|c|c|c|}
\hline Country & Ailment/Use & Part Used/ Dosage Form & Route of Administration & References \\
\hline \multirow{2}{*}{ Lithuania } & Chest pain, diarrhea & Rhizomes and leaves are taken with sugar & & [52] \\
\hline & Relieves pain, gout, rheumatism & Leaves decoction & External & [61] \\
\hline New Guinea & Miscarriage & \multirow{9}{*}{ Rhizomes } & \multirow{4}{*}{ Oral } & {$[62]$} \\
\hline Philippines & Gastrointestinal, rheumatism & & & [56] \\
\hline Russia & $\begin{array}{l}\text { Typhoid, syphilis, baldness, } \\
\text { fever, cholera }\end{array}$ & & & [63] \\
\hline Thailand & Blood purifier, fever & & & [64] \\
\hline \multirow{2}{*}{ Turkey } & $\begin{array}{l}\text { Wound healing, cough, } \\
\text { tuberculosis }\end{array}$ & & External and oral & {$[61]$} \\
\hline & Gastrointestinal & & \multirow{7}{*}{ Oral } & {$[65,66]$} \\
\hline $\begin{array}{c}\text { Arab } \\
\text { countries }\end{array}$ & Gastrointestinal, tuberculosis & & & {$[67,68]$} \\
\hline Brazil & Destroys parasitic worms & & & [68] \\
\hline Argentina & Dysmenorrhea & & & [69] \\
\hline United States & $\begin{array}{c}\text { Gastrointestinal, abortifacient, } \\
\text { stimulant, tonic, } \\
\text { respiratory disorder }\end{array}$ & \multirow[t]{2}{*}{ Rhizomes } & & [70] \\
\hline Korea & Improves memory and life span & & & [71] \\
\hline Sri Lanka & Cough, worm infestation & Rhizomes paste are given with milk & & [72] \\
\hline
\end{tabular}


Table 2. Pharmaceutical products of $A$. calamus available in the market.

\begin{tabular}{|c|c|c|}
\hline Medicine/Formulations & Indications/Use & Manufacturers \\
\hline Pilochek tablets & Hemorrhoids & \multirow{4}{*}{ Dabur India Limited } \\
\hline Brahm Rasayan & Nervine tonic & \\
\hline Mahasudarsan Churna & Malaria & \\
\hline Janma Ghunti Honey & Babies growth, Constipation, Diarrhea & \\
\hline Brahmi Pearls capsules & Brain Nourisher & \multirow{5}{*}{ Kerala Ayurveda } \\
\hline GT capsules & Osteoarthritis, osteoporosis, hyperlipidemia & \\
\hline Histantin tablets & Anti-allergic & \\
\hline Santhwanam oil & Antioxidant, rejuvenate & \\
\hline Mahathikthaka Ghrita capsules & Skin disease, malabsorption syndrome & \\
\hline Calamus root tincture & Stimulates the digestive system & Florida Herbal Pharmacy \\
\hline Vacha capsules & Food supplements & DR Wakde's Natural Health Care, London \\
\hline Mentat tablets and syrup & Nervine tonic & \multirow{8}{*}{ Himalaya Herbal Healthcare } \\
\hline Abana & Cardiovascular disorders, hyperlipidemia, dyslipidemia & \\
\hline Mentat tablets and Syrup & Anxiety, depression, insomnia & \\
\hline Muscle \& Joint Rub & Backaches, muscular sprains, pain & \\
\hline Anxocare & Anxiety & \\
\hline Erina-EP & Ectoparasites & \\
\hline Himpyrin, Himpyrin Vet & Analgesic and anti-inflammatory & \\
\hline Scavon Vet & Anti-bacterial, anti-fungal & \\
\hline Vacha powder & Brain tonic, improves digestion, and prevents nausea & Bixa Botanical \\
\hline Amalth & Herbal supplements & Mcnow Biocare Private Limited \\
\hline Sunarin capsules & Anal fissures, piles, rectal inflammation, congestion & SG Phyto Pharma \\
\hline
\end{tabular}


Table 2. Cont

\begin{tabular}{|c|c|c|}
\hline Medicine/Formulations & Indications/Use & Manufacturers \\
\hline $\begin{array}{l}\text { Dr Willmar Schwabe India Acorus calamus } \\
\text { mother tincture }\end{array}$ & Intestinal worms and stomach disorders, fever, nausea & Dr Willmar Schwabe India Pvt Ltd. \\
\hline Himalayan calamus root essential oil & Pain relief and calm mind & Naturalis Essence of Nature \\
\hline Calamus oil & Body, skin care, hair growth & Kazima Perfumers \\
\hline Calamus root powder & Mental health problems & Heilen Biopharm \\
\hline Winton tablets and syrup & Reduce tension, stress, and anxiety & Scortis Healthcare \\
\hline Chesol syrup & Muscular aches and pains, chest colds, and bronchitis & J \& J Dechane Laboratories Private Limited \\
\hline Enzo Fast & Acidity, gastritis, flatulence, indigestion & Naturava \\
\hline Dark Forest Vekhand powder & Abdomen pain, worms (infants) & Simandhar Herbal Pvt. Ltd. \\
\hline Nervocare & Insomnia & Deep Ayurveda \\
\hline Antress tablets & Anxiety and stress disorders & Ayursun Pharma \\
\hline Grapzone syrup & Mental wellness & Alna Biotech Pvt Ltd. \\
\hline Memoctive syrup & Improves memory power & Aayursh Herbal India \\
\hline Smrutihills capsules & Stress, anxiety, adaptogenic & Ayush Arogyam \\
\hline Gastrin capsules & Gastritis, dyspepsia & Sarvana Marundhagam \\
\hline Pigmento tablets & Leukoderma or vitiligo & \multirow{2}{*}{ Charak Pharma } \\
\hline Paedritone drops & Digestive functions & \\
\hline Vacha Churna & Brain tonic, digestion, nausea & Sadvaidyasala \\
\hline Alert capsules & Immunomodulator, anxiety & Vasu Healthcare \\
\hline Brento tablets & Increasing cognitive functions & \multirow{3}{*}{ Zandu Realty Limited } \\
\hline Livotrit Forte & Hepatitis, jaundice & \\
\hline Zanduzyme & Indigestion and dyspepsia & \\
\hline
\end{tabular}


Table 2. Cont

\begin{tabular}{|c|c|c|}
\hline Medicine/Formulations & Indications/Use & Manufacturers \\
\hline Vedic Slim & Anti-obesity & Vedic Bio-Labs Pvt. Ltd. \\
\hline Hinguvachaadi Gulika & Anorexia, indigestion, appetite loss & Nagarajuna Pvt. Ltd. \\
\hline Nilsin capsules & Sinusitis and allergic rhinitis & Phytomarketing \\
\hline Norbeepee tablet & Hypertension & AVN Formulations \\
\hline Sooktyn tablet & Antacid, antispasmodic & Alarsin Pharma Pvt. Ltd. \\
\hline Deonac oil & Pain reliving oil & Doux Healthcare Pvt. Ltd. \\
\hline Smrutisagar Rasa & Memory enhancer & \multirow{2}{*}{ Shree Dhootpapeshwar Limited } \\
\hline Yogaraj Guggul & Vitiligo, anorexia, indigestion, loss of appetite & \\
\hline Kankayan Bati & Gastritis, flatulence, dyspepsia & \multirow{2}{*}{ Baidyanath Pvt. Ltd. } \\
\hline Brahmi Ghrita & Insanity and memory issues & \\
\hline Fat Go & Controls high cholesterol level & Jolly Healthcare \\
\hline Divya Medha Vati & Improves memory power & \multirow{2}{*}{ Patanjali Ayurveda } \\
\hline Divya Mukta Vati & High blood pressure & \\
\hline
\end{tabular}




\section{Phytochemistry}

The phytochemical investigation of this plant has been ongoing since the year 1957 [73,74]. To date, about 145 compounds were isolated from $A$. calamus rhizomes and leaves, viz. phenylpropanoids, sterols, triterpene glycosides, triterpenoid saponins, sesquiterpenoids, monoterpenes, and alkaloids (Table 3). Amongst those, phenylpropanoids (chiefly, asarone and eugenol) and sesquiterpenoids have been considered the principal effective compounds of A. calamus. Chemical structures of isolated compounds from A. calamus are illustrated in Figure 5.
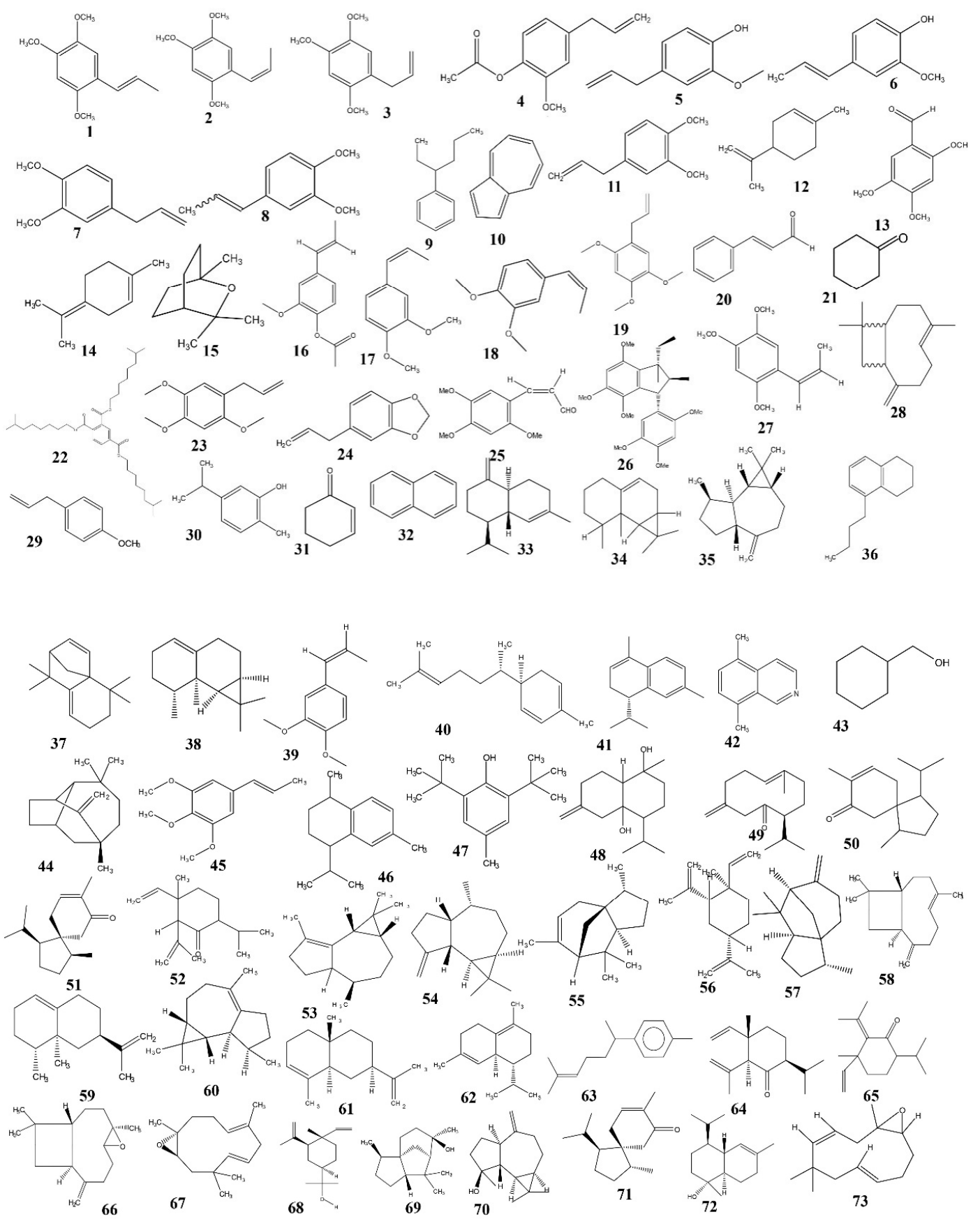

Figure 5. Cont. 

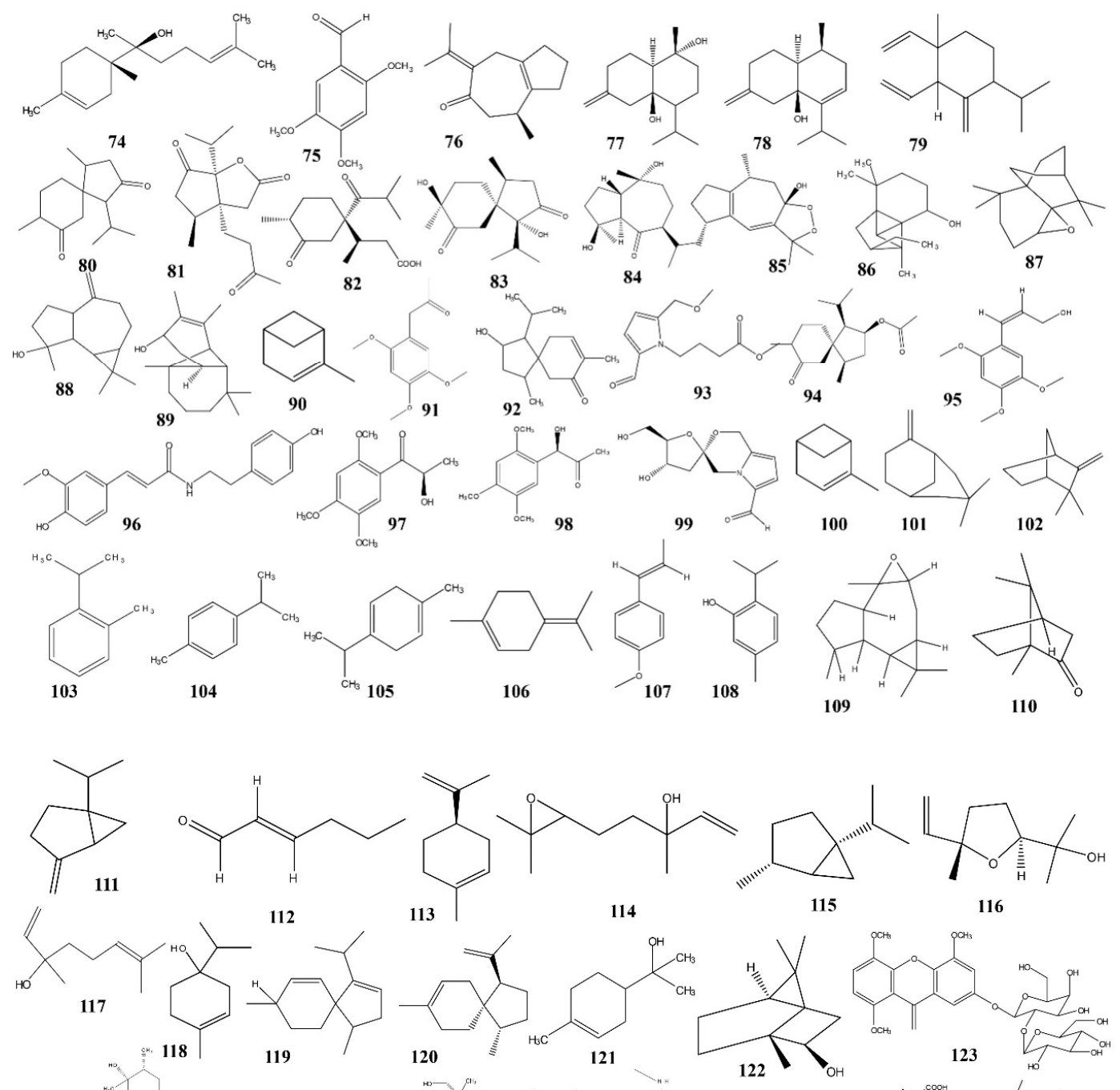

124
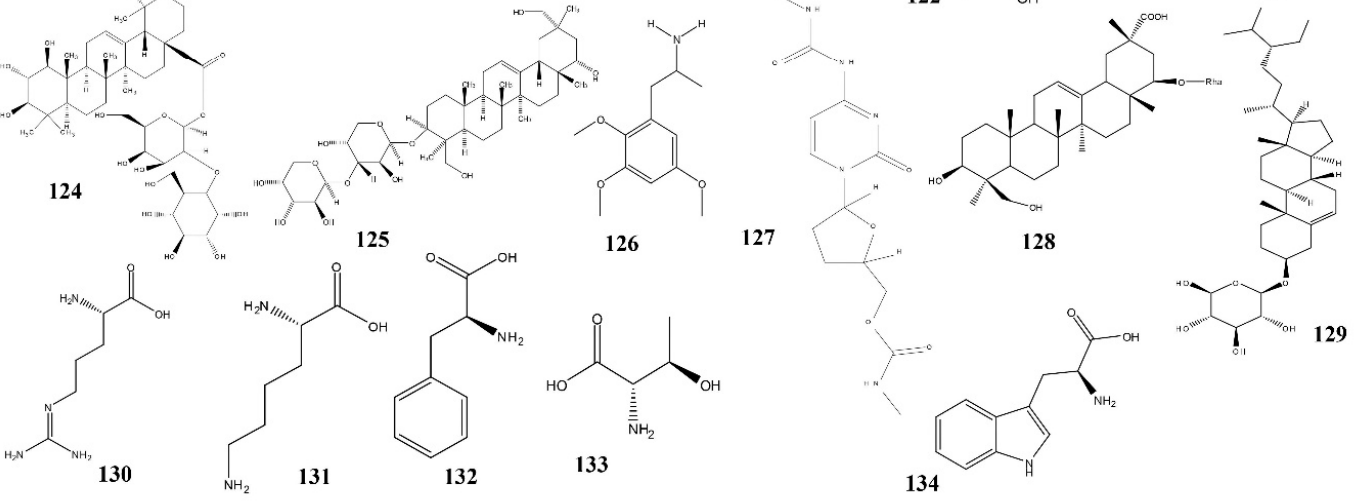

Figure 5. Cont. 
<smiles>C[C@H](N)C(=O)NNC(=O)C[C@H](N)C(=O)O</smiles>

135<smiles>CCCCCCCCCCCCCCCCCC(=O)O</smiles><smiles>CCC[C@H](N)C(=O)O</smiles>

138<smiles>O=C(O)[C@@H]1CCCN1</smiles>

139

Figure 5. Chemical structures of isolated compounds from A. calamus.

\subsection{Phenylpropanoids}

Phenylpropanoids have an aromatic ring with a structurally diverse group of phenylalaninederived secondary plant metabolites $\left(\mathrm{C}_{6}-\mathrm{C}_{3}\right)$, like $\alpha$-asarone, $\beta$-asarone, eugenol, isoeugenol, etc. [75]. A number of phenylpropanoids have been identified from A. calamus rhizome and leaves (1-45). $\alpha$ and $\beta$-asarone isolated from the rhizome are the predominant compounds present in this plant. A series of aromatic oils from the rhizome with diverse structures are also reported [74-98]. 
Table 3. Chemical compounds isolated from different botanical parts of $A$. calamus.

\begin{tabular}{|c|c|c|c|c|c|}
\hline Classification & Compound No. & Chemical Ingredient & $\begin{array}{c}\text { Methods of } \\
\text { Characterization }\end{array}$ & Parts/Extract & References \\
\hline \multirow{24}{*}{ Phenylpropanoids } & 1 & $\alpha$-Asarone & \multirow{3}{*}{ GC-FID, GC-MS } & \multirow{3}{*}{$\begin{array}{l}\text { Rhizomes/n-hexane, aqueous, } \\
\text { methanol, ethanol }\end{array}$} & \multirow{3}{*}[74,78,84,89-91]{} \\
\hline & 2 & $\beta$-Asarone & & & \\
\hline & 3 & $\gamma$-Asarone & & & \\
\hline & 4 & Eugenyl acetate & \multirow{12}{*}{ GC-MS } & \multirow{3}{*}{ Rhizomes/aqueous extract } & \multirow{3}{*}[74,78,91]{} \\
\hline & 5 & Eugenol & & & \\
\hline & 6 & Isoeugenol & & & \\
\hline & 7 & Methyl eugenol & & $\begin{array}{l}\text { Rhizomes/n-hexane, } \\
\text { ethyl acetate }\end{array}$ & [92] \\
\hline & 8 & Methyl isoeugenol & & Rhizomes/hexane & {$[74,78,91,94]$} \\
\hline & 9 & Calamol & & \multirow{9}{*}{ Rhizomes/aqueous extract } & \multirow{7}{*}[74,78,91]{} \\
\hline & 10 & Azulene & & & \\
\hline & 11 & Eugenol methyl ether & & & \\
\hline & 12 & Dipentene & & & \\
\hline & 13 & Asaronaldehyde & & & \\
\hline & 14 & Terpinolene & & & \\
\hline & 15 & 1,8-cineole & & & \\
\hline & 16 & $(E)$-isoeugenol acetate & \multirow{5}{*}{ GC-FID, GC-MS } & & \multirow{2}{*}{ [89] } \\
\hline & 17 & $(E)$-methyl isoeugenol & & & \\
\hline & 18 & Cis-methyl isoeugenol & & \multirow{3}{*}{ Rhizomes/n-hexane, ethyl acetate } & \multirow{3}{*}{ [92] } \\
\hline & 19 & Euasarone & & & \\
\hline & 20 & Cinnamaldehyde & & & \\
\hline & 21 & Cyclohexanone & GC-MS & Rhizomes/hexane & [94] \\
\hline & 22 & Acorin & \multirow{3}{*}{ NMR } & \multirow{3}{*}{ Rhizomes/chloroform } & \multirow{3}{*}{ [95] } \\
\hline & 23 & Isoasarone & & & \\
\hline & 24 & Safrole & & & \\
\hline
\end{tabular}


Table 3. Cont

\begin{tabular}{|c|c|c|c|c|c|}
\hline Classification & Compound No. & Chemical Ingredient & $\begin{array}{c}\text { Methods of } \\
\text { Characterization }\end{array}$ & Parts/Extract & References \\
\hline \multirow{22}{*}{ Phenylpropanoids } & 24 & Safrole & \multirow{3}{*}{ FTIR, NMR } & & \\
\hline & 25 & Z-3-(2,4,5-trimethoxyphenyl)-2-propenal & & \multirow{2}{*}{ Rhizomes/ethanol } & \multirow{2}{*}{ [96] } \\
\hline & 26 & $\begin{array}{l}\text { 2,3-dihydro-4,5,7-trimethoxy-1-ethyl-2-methyl-3 } \\
\text { (2,4,5-trimethoxyphenyl) indene }\end{array}$ & & & \\
\hline & 27 & (Z)-asarone & \multirow{19}{*}{ GC-MS } & \multirow{2}{*}{ Leaves/n-hexane } & \multirow{2}{*}{ [97] } \\
\hline & 28 & (E)-caryophyllene & & & \\
\hline & 29 & Estragole & & \multirow{17}{*}{ Rhizomes/aqueous } & \multirow{17}{*}{ [98] } \\
\hline & 30 & Carvacrol & & & \\
\hline & 31 & 2-cyclohexane-1-one & & & \\
\hline & 32 & Naphthalene & & & \\
\hline & 33 & $\gamma$-Cadinene & & & \\
\hline & 34 & Aristolene & & & \\
\hline & 35 & 1(5),3-aromadenedradiene & & & \\
\hline & 36 & 5-n-butyltetraline & & & \\
\hline & 37 & 4,5-dehydro-isolongifolene & & & \\
\hline & 38 & Calarene & & & \\
\hline & 39 & Isohomogenol & & & \\
\hline & 40 & Zingiberene & & & \\
\hline & 41 & $\alpha$-Calacorene & & & \\
\hline & 42 & 5,8-dimethyl isoquinoline & & & \\
\hline & 43 & Cyclohexane methanol & & & \\
\hline & 44 & Longifolene & & & \\
\hline & 45 & Isoelemicin & & & \\
\hline
\end{tabular}


Table 3. Cont

\begin{tabular}{|c|c|c|c|c|c|}
\hline Classification & Compound No. & Chemical Ingredient & $\begin{array}{c}\text { Methods of } \\
\text { Characterization }\end{array}$ & Parts/Extract & References \\
\hline \multirow{29}{*}{ Sesquiterpenoids } & 46 & Calamene & & \multirow{29}{*}{ Rhizomes/aqueous } & \multirow{4}{*}[74,78,91]{} \\
\hline & 47 & Calamenenol & & & \\
\hline & 48 & Calameone & & & \\
\hline & 49 & Preisocalamendiol & & & \\
\hline & 50 & 1,4-(trans)1,7(trans)-acorenone & & & \multirow{5}{*}{ [93] } \\
\hline & 51 & 1,4-(cis)-1,7-(trans)-acorenone & & & \\
\hline & 52 & 2,6 diepishyobunone & & & \\
\hline & 53 & $\alpha$-Gurjunene & & & \\
\hline & 54 & $\beta$-Gurjunene & & & \\
\hline & 55 & $\alpha$-Cedrene & & & \multirow{2}{*}{ [98] } \\
\hline & 56 & $\beta$-Elemene & & & \\
\hline & 57 & $\beta$-Cedrene & & & \multirow{4}{*}{ [93] } \\
\hline & 58 & $\beta$-Caryophyllene & & & \\
\hline & 59 & Valencene & & & \\
\hline & 60 & Viridiflorene & & & \\
\hline & 61 & $\alpha$-Selinene & GC-FID, GC-MS & & {$[89,93]$} \\
\hline & 62 & $\delta$-Cadinene & \multirow{5}{*}{ GC-MS } & & \multirow{2}{*}{ [93] } \\
\hline & 63 & $\alpha$-Curcumene & & & \\
\hline & 64 & Shyobunone & & & {$[84,93,99,100]$} \\
\hline & 65 & Isoshyobunone & & & {$[93,99,101]$} \\
\hline & 66 & Caryophyllene oxide & & & [93] \\
\hline & 67 & Humulene oxide II & GC-FID, GC-MS & & {$[89,93]$} \\
\hline & 68 & Elemol & \multirow{5}{*}{ GC-MS } & & \multirow{5}{*}{ [93] } \\
\hline & 69 & Cedrol & & & \\
\hline & 70 & Spathulenol & & & \\
\hline & 71 & Acorenone & & & \\
\hline & 72 & $\alpha$-Cadinol & & & \\
\hline & 73 & Humulene epoxide II & \multirow{2}{*}{ GC-FID, GC-MS } & & \multirow{2}{*}{ [89] } \\
\hline & 74 & $\alpha$-Bisabolol & & & \\
\hline
\end{tabular}


Table 3. Cont

\begin{tabular}{|c|c|c|c|c|c|}
\hline Classification & Compound No. & Chemical Ingredient & $\begin{array}{c}\text { Methods of } \\
\text { Characterization }\end{array}$ & Parts/Extract & References \\
\hline \multirow{25}{*}{ Sesquiterpenoids } & 75 & Asaronaldehyde & NMR & Rhizomes/chloroform & [95] \\
\hline & 76 & Calamusenone & \multirow{4}{*}{ GLC, IR, NMR } & \multirow{4}{*}{ Rhizomes/petroleum ether } & \multirow{4}{*}{ [99] } \\
\hline & 77 & Isocalamendiol & & & \\
\hline & 78 & Dehydroxyiso-calamendiol & & & \\
\hline & 79 & Epishyobunone & & & \\
\hline & 80 & Acorone & \multirow{5}{*}{ NMR } & Rhizomes/hydro alcoholic & [100] \\
\hline & 81 & Neo-acorane A & & \multirow{4}{*}{ Rhizomes/ethanol } & \multirow{3}{*}{ [102] } \\
\hline & 82 & Acoric acid & & & \\
\hline & 83 & Calamusin D & & & \\
\hline & 84 & $1 \beta, 5 \alpha$-Guaiane- $4 \beta, 10 \alpha$-diol-6-one & & & [103] \\
\hline & 85 & Dioxosarcoguaiacol & HPLC & Rhizomes/petroleum ether & [101] \\
\hline & 86 & 7-tetracycloundecanol,4,4,11,11-tetramethyl & \multirow{4}{*}{ GC-MS } & \multirow{2}{*}{ Rhizomes/ethanol } & \multirow{2}{*}{ [84] } \\
\hline & 87 & $4 \alpha, 7$-Methano-4 $\alpha$-naphth $[1,8 \mathrm{a}-\mathrm{b}]$ oxirene, & & & \\
\hline & 88 & Spathulenol & & \multirow{2}{*}{ Rhizomes/aqueous } & \multirow{2}{*}{ [98] } \\
\hline & 89 & Vulgarol B & & & \\
\hline & 90 & Tatanan A & \multirow{10}{*}{ HPLC, NMR } & \multirow{10}{*}{ Rhizomes/95\% ethanol } & \multirow{10}{*}{ [104] } \\
\hline & 91 & Acoramone & & & \\
\hline & 92 & 2-hydroxyacorenone & & & \\
\hline & 93 & $\begin{array}{c}\text { 4-(2-formyl-5-methoxymethyl } \\
\text { pyrrol-1-yl) butyric acid methyl ester }\end{array}$ & & & \\
\hline & 94 & 2-acetoxyacorenone & & & \\
\hline & 95 & Acoramol & & & \\
\hline & 96 & $\begin{array}{l}\mathrm{N} \text {-transferuloyl } \\
\text { tyramine }\end{array}$ & & & \\
\hline & 97 & Tatarinoid A & & & \\
\hline & 98 & Tatarinoid B & & & \\
\hline & 99 & Acortatarin A & & & \\
\hline
\end{tabular}


Table 3. Cont.

\begin{tabular}{|c|c|c|c|c|c|}
\hline Classification & Compound No. & Chemical Ingredient & $\begin{array}{c}\text { Methods of } \\
\text { Characterization }\end{array}$ & Parts/Extract & References \\
\hline \multirow{23}{*}{ Monoterpenes } & 100 & $\alpha$-Pinene & \multirow{4}{*}{ GC-MS } & \multirow{10}{*}{ Rhizomes, roots/aqueous } & \multirow[t]{2}{*}[74,78,91,93]{} \\
\hline & 101 & $\beta$-Pinene & & & \\
\hline & 102 & Camphene & & & {$[74,78,91,93,98]$} \\
\hline & 103 & o-Cymol & & & {$[98]$} \\
\hline & 104 & p-Cymene & GC-FID, GC-MS & & {$[89,93,98]$} \\
\hline & 105 & $\gamma$-Terpinene & \multirow{18}{*}{ GC-MS } & & \multirow{5}{*}{ [98] } \\
\hline & 106 & $\alpha$-Terpinolene & & & \\
\hline & 107 & Anethole & & & \\
\hline & 108 & Thymol & & & \\
\hline & 109 & Isoaromadendrene epoxide & & & \\
\hline & 110 & Camphor & & $\begin{array}{l}\text { Rhizome, leaves, roots/aqueous, } \\
\text { hexane }\end{array}$ & {$[93,97]$} \\
\hline & 111 & Sabinene & & \multirow{11}{*}{ Roots/aqueous } & \multirow[b]{2}{*}{ [93] } \\
\hline & 112 & 2-hexenal & & & \\
\hline & 113 & Limonene & & & {$[93,98]$} \\
\hline & 114 & Cis-linaloloxide & & & \multirow{3}{*}{ [93] } \\
\hline & 115 & Cis-sabinene hydrate & & & \\
\hline & 116 & Trans-linalol oxide & & & \\
\hline & 117 & Linalool & & & {$[93,97]$} \\
\hline & 118 & Terpinen-4-ol & & & \multirow{4}{*}{ [93] } \\
\hline & 119 & $\alpha$-Acoradiene & & & \\
\hline & 120 & $\beta$-Acoradiene & & & \\
\hline & 121 & $\alpha$-Terpineol & & & \\
\hline & 122 & Isoborneol & & Leaves/hexane & [97] \\
\hline
\end{tabular}


Table 3. Cont

\begin{tabular}{|c|c|c|c|c|c|}
\hline Classification & Compound No. & Chemical Ingredient & $\begin{array}{c}\text { Methods of } \\
\text { Characterization }\end{array}$ & Parts/Extract & References \\
\hline Xanthone glycosides & 123 & $\begin{array}{l}\text { 4,5,8-trimethoxy-xanthone-2-O- } \beta \text {-D-glucopyranosyl } \\
\text { (1-2)-O- } \beta \text {-D-galactopyranoside }\end{array}$ & & \multirow{5}{*}{ Rhizome/ethanol } & [83] \\
\hline \multirow{2}{*}{$\begin{array}{l}\text { Triterpenoid } \\
\text { saponins }\end{array}$} & 124 & 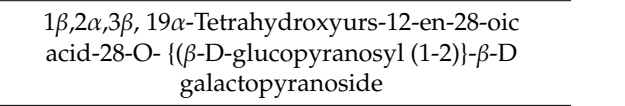 & NMR & & \multirow{2}{*}{ [82] } \\
\hline & 125 & $\begin{array}{c}3-\beta, \\
\text { 22- } \alpha-24,29-\text { Tetrahydroxyolean-12-en-3-O-( } \beta \text {-Darabinosyl } \\
(1,3)\}-\beta \text {-D-arabinopyranoside }\end{array}$ & & & \\
\hline \multirow[b]{2}{*}{ Alkaloids } & 126 & Trimethoxyamphetamine, $2,3,5$ & \multirow[b]{2}{*}{ GC-MS } & & \multirow{2}{*}{ [84] } \\
\hline & 127 & $\begin{array}{l}\text { Pyrimidin-2-one,4-[N-methylureido]-1-[4methyl } \\
\text { amino carbonloxy methy] }\end{array}$ & & & \\
\hline Triterpene glycoside & 128 & $\begin{array}{l}\text { 22-[(6-deoxy- } \alpha \text {-L-rhamnopyranosyl) } \\
\text { oxy]-3,23-dihydroxy-, methyl ester, }(3 \beta, 4 \beta, 20 \alpha, 22 \beta)\end{array}$ & \multirow[t]{2}{*}{ NMR } & \multirow[t]{2}{*}{ Root, Rhizomes/ethyl acetate } & \multirow[t]{2}{*}{ [85] } \\
\hline Steroids/Sterols & 129 & $\beta$-daucosterol & & & \\
\hline \multirow{12}{*}{ Amino acids } & 130 & Arginine & \multirow{12}{*}{ HPLC } & \multirow{12}{*}{ Roots/ethanol } & \multirow{12}{*}[86,87]{} \\
\hline & 131 & Lysine & & & \\
\hline & 132 & Phenylalanine & & & \\
\hline & 133 & Threonine & & & \\
\hline & 134 & Tryptophan & & & \\
\hline & 135 & $\alpha$-alanine & & & \\
\hline & 136 & Asparagine & & & \\
\hline & 137 & Aspartic acid & & & \\
\hline & 138 & Norvaline & & & \\
\hline & 139 & Proline & & & \\
\hline & 140 & Tyrosine & & & \\
\hline & 141 & Glutamic acid & & & \\
\hline \multirow{4}{*}{ Fatty acids } & 142 & Palmitic acid & \multirow{4}{*}{ GLC } & \multirow{4}{*}{ Rhizome/petroleum ether } & \multirow{4}{*}{ [88] } \\
\hline & 143 & Myristic acid & & & \\
\hline & 144 & Palmitoleic acid & & & \\
\hline & 145 & Stearic acid & & & \\
\hline
\end{tabular}

GC-FID, gas chromatography - flame ionization detector; GC-MS, gas chromatography - mass spectrometry; NMR, nuclear magnetic resonance; FTIR, Fourier-transform infrared spectroscopy; GLC, gas liquid chromatography; IR, infrared spectroscopy; HPLC, high-performance liquid chromatography. 


\subsection{Sesquiterpenoids}

About 44 sesquiterpenes, including lactones, were characterized and identified in A. calamus rhizomes. Sesquiterpene lactones are produced of 3 isoprene units and composed of lactone rings. $\alpha-\beta$ unsaturated $\gamma$-lactonic ring in sesquiterpene lactones is believed to be responsible for pharmacological activity (46-99) [74,78,89,91,93,98-104].

\subsection{Monoterpenes}

Monoterpenes (C-10) are the simplest class of the terpene series that belongs to two isoprene units (tricyclic, bicyclic, monocyclic, etc.). Monoterpenes can have different functional groups, like aldehydes, ketones, esters, ethers, phenols, and alcohols [80]. These organic compounds emit the characteristic flavor and fragrance of $A$. calamus leaves and rhizomes (100-122) [74,78,89,91,93,97,98].

\subsection{Triterpenoid Saponins}

Triterpenoid saponins are made up of a pentacyclic C-30 terpene skeleton as a pillar. Limited reports studying triterpenoid saponins in A. calamus are available, and only two triterpenoid saponins $(124,125)$ have been isolated from A. calamus rhizomes (Table 3) [85].

\subsection{Other Compounds}

To date, one xanthone glycoside (123) [82,83], two alkaloids (126-127) [84], one triterpene glycoside (128), one steroid (129) [85], 12 amino acids (130-141) [86,87], and 4 fatty acids (142-145) [88] have been identified in A. calamus rhizomes [83-88].

\section{Pharmacological Properties}

Diverse bioactivities of $A$. calamus extracts are evident from preclinical (in vitro and in vivo) and clinical reports, such as antidiabetic, anti-obesity, antihypertensive, antioxidant, anti-inflammatory, immunomodulatory, anticonvulsant, and neuroprotective [105-173]. The summarized information on A. calamus botanical parts, extract type, and their bioactivities in neurological and metabolic disorders is stipulated in Table 4. 
Table 4. Preclinical claims of A. calamus in neurological and metabolic disorders.

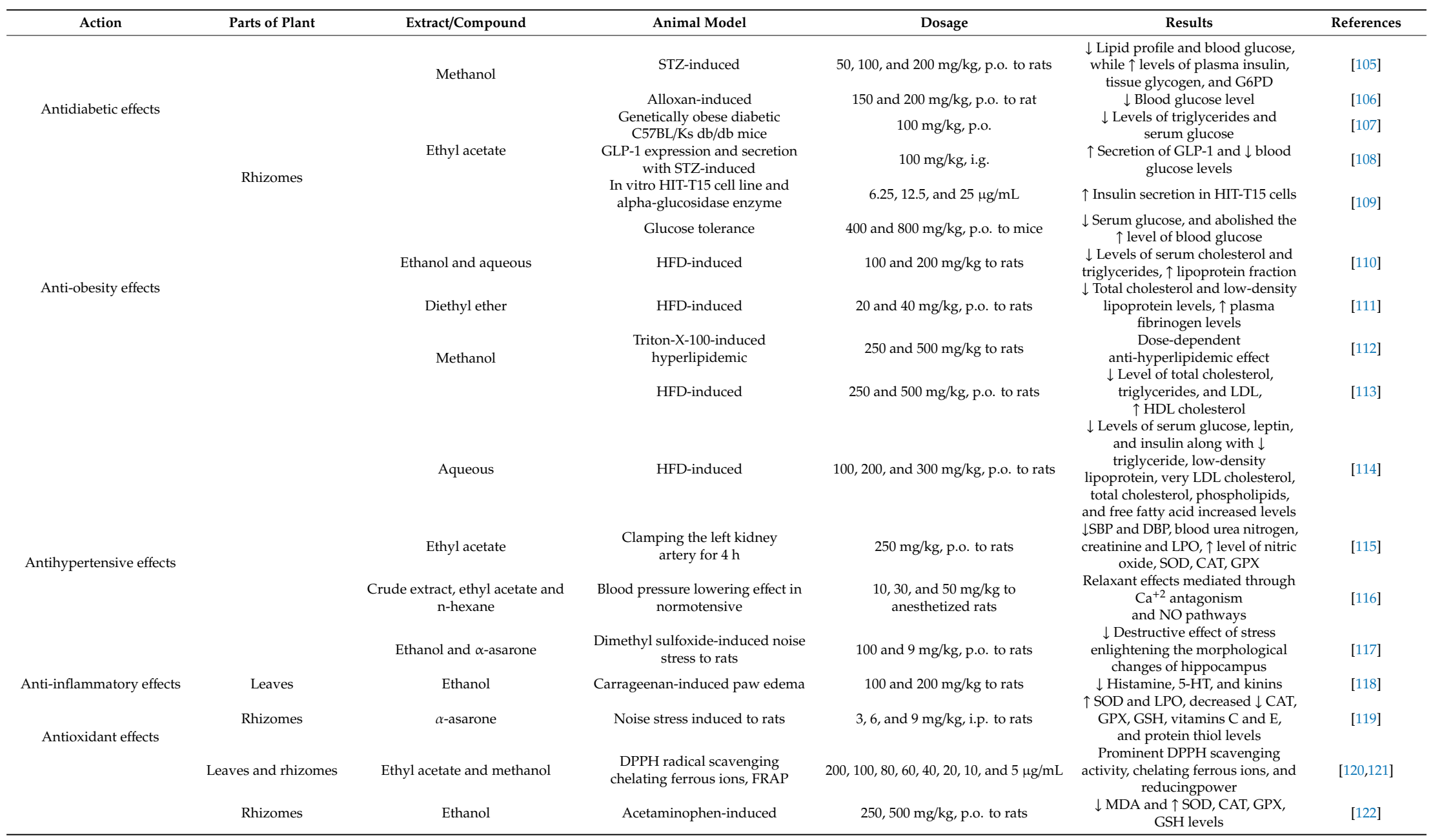


Table 4. Cont

\begin{tabular}{|c|c|c|c|c|c|c|}
\hline Action & Parts of Plant & Extract/Compound & Animal Model & Dosage & Results & References \\
\hline \multirow{4}{*}{ Anticonvulsant effects } & Roots & Ethanol and $\beta$-asarone & Kainic acid-induced convulsion & 35 and $20 \mathrm{mg} / \mathrm{kg}$ & $\begin{array}{c}\downarrow \text { Epileptic seizure, } \\
\text { neuroprotective, } \\
\text { and regenerative ability }\end{array}$ & [123] \\
\hline & & Methanol & PTZ-induced convulsion & 100 and $200 \mathrm{mg} / \mathrm{kg}$, p.o. to mice & $\begin{array}{l}\uparrow \text { Latency period and } \downarrow \\
\text { PTZ-induced seizure time }\end{array}$ & [124] \\
\hline & & Calamus oil & MES, PTZ, and MCS model & 30,100 , and $300 \mathrm{mg} / \mathrm{kg}$, p.o. to mice & Calamus oil is found stable & [125] \\
\hline & Rhizomes & Ethanol & MES and PTZ-induced convulsion & $250,500 \mathrm{mg} / \mathrm{kg}$, p.o. to mice & $\begin{array}{l}\downarrow \text { Hind limb extension and tonic } \\
\text { flexion of forelimbs }\end{array}$ & [126] \\
\hline \multirow{7}{*}{ Antidepressant effects } & & Methanol & MES and PTZ-induced & 250 and $150 \mathrm{mg} / \mathrm{kg}$, p.o. to rats & $\begin{array}{l}\downarrow \text { Immobility time at } 250 \mathrm{mg} / \mathrm{kg} \text {; } \\
\text { however, ineffective at } 150 \mathrm{mg} / \mathrm{kg}\end{array}$ & [127] \\
\hline & & мvetrator & TST and FST & 50 and $100 \mathrm{mg} / \mathrm{kg}$, i.p. to mice & $\begin{array}{l}\downarrow \text { Immobility time in a } \\
\text { dose-dependent manner }\end{array}$ & [128] \\
\hline & Leaves & & TST and FST & 50 and $100 \mathrm{mg} / \mathrm{kg}$ & $\downarrow$ Immobility time & [129] \\
\hline & Roots & Aqueous & TST and FST & $100,150,200 \mathrm{mg} / \mathrm{kg}$, p.o. to mice & $\downarrow$ Immobility time & [130] \\
\hline & \multirow{3}{*}{ Rhizomes } & Hydro-alcoholic extract & TST and FST & 75 and $150 \mathrm{mg} / \mathrm{kg}$, p.o. to mice & $\downarrow$ Corticosteroid levels & [131] \\
\hline & & Ethanol & OFB and HPM test & 72 mg/kg, p.o. & $\begin{array}{l}\text { No stimulation of postsynaptic } \\
\text { 5-HT1A receptors }\end{array}$ & [132] \\
\hline & & $\begin{array}{l}\text { Methanol and acetone } \\
\beta \text {-asarone }\end{array}$ & $\begin{array}{l}\text { Behavioral despair test } \\
\text { EPM and FST }\end{array}$ & $\begin{array}{l}\text { 5, 20, and } 50 \mathrm{mg} / \mathrm{kg} \text {, p.o. } \\
25,50 \text {, and } 100 \mathrm{mg} / \mathrm{kg} \text {, p.o. }\end{array}$ & $\begin{array}{c}\downarrow \text { Spontaneous locomotor activity } \\
\downarrow \downarrow \text { Immobility time }\end{array}$ & $\begin{array}{l}{[133]} \\
{[134]}\end{array}$ \\
\hline \multirow{5}{*}{ Neuroprotective effects } & & Hydro-alcoholic & $\begin{array}{l}\text { CCI of sciatic nerve-induced } \\
\text { neuropathic pain }\end{array}$ & $10 \mathrm{mg} / \mathrm{kg}$ to rats & $\begin{array}{l}\text { Significantly ameliorated } \\
\text { CCI-induced nociceptive pain }\end{array}$ & [135] \\
\hline & & & $\begin{array}{l}\text { CCI of sciatic nerve-induced } \\
\text { peripheral neuropathy }\end{array}$ & 100 and $200 \mathrm{mg} / \mathrm{kg}$ to rats & $\begin{array}{l}\text { Prevented CCI-induced } \\
\text { neuropathy through } \downarrow \text { oxidation } \\
\text { and inflammation }\end{array}$ & [136] \\
\hline & Leaves & Methanol and acetone & $\begin{array}{l}\text { Apomorphine-induced stereotypy } \\
\text { and haloperidol-induced catalepsy }\end{array}$ & 20 and $50 \mathrm{mg} / \mathrm{kg}$ to mice & $\begin{array}{l}\text { Reversed stereotypy induced by } \\
\text { apomorphine and significantly } \\
\text { potentiated catalepsy } \\
\text { induced by haloperidol }\end{array}$ & [137] \\
\hline & Rhizomes & Ethanol & $\begin{array}{l}\text { Spontaneous electrical activity and } \\
\text { monoamine levels of the brain }\end{array}$ & 200 and $300 \mathrm{mg} / \mathrm{kg}$ to rats & $\begin{array}{l}\text { Depressive response by altering } \\
\text { electrical activity, including } \\
\text { changing brain monoamine levels } \\
\text { Improvement in neurobehavioral }\end{array}$ & [138] \\
\hline & & Hydro-alcoholic & MCAo-produced brain ischemia & $25 \mathrm{mg} / \mathrm{kg}$ to rats & $\begin{array}{c}\text { performance, } \downarrow \text { levels of GSH, SOD, } \\
\text { and } \uparrow \text { LPO level }\end{array}$ & [139] \\
\hline \multirow{3}{*}{ Cardioprotective effects } & & Ethanol & Methotrexate-induced stress & $\begin{array}{l}5,10,15,20,25 \mathrm{ppm} \text { concentration to } \\
\text { fruit flies }\end{array}$ & $\begin{array}{c}\downarrow \text { Elevated ROS, sOD, CAT, and } \\
\text { GPX levels }\end{array}$ & [140] \\
\hline & Whole plant & & DOX-induced myocardial toxicity & 100 and $200 \mathrm{mg} / \mathrm{kg}$ to rats & $\begin{array}{l}\downarrow \text { Serum enzyme levels and } \\
\text { protected the myocardium from } \\
\text { the toxic effect of DOX }\end{array}$ & [141] \\
\hline & Rhizomes & Crude, n-hexane, ethyl acetate & Guinea pig tracheal segments & $0.01 \mathrm{mg} / \mathrm{mL}$ & $\begin{array}{l}\downarrow \text { Force and rate of contractions at } \\
\text { higher concentrations }\end{array}$ & [142] \\
\hline
\end{tabular}

CAT, catalase; $\mathrm{CCI}$, chronic constriction injury; COX, cyclooxygenase; DBP, diastolic blood pressure; DOX, doxorubicin; DPPH, 2,2-diphenyl-1-picrylhydrazyl radical; EPM, elevated plus maze; FRAP, ferric reducing antioxidant power; FST, forced swim test; GLP-1, glucagon-like peptide-1; GPX, glutathione peroxidase; GR, glutathione reductase; GSH, reduced glutathione; HDL, high-density lipoproteins; HFD, high-fat diet; HPM, high plus maze; i.g., intragastric; i.p., intraperitoneal; LDL, low-density lipoprotein; LPO, lipid peroxides; MCAo, middle cerebral artery occlusion; MCS, minimal clonic seizure; MDA, malondialdehyde; MES, maximal electroshock; NO, nitric oxide; OFB, open field behavior; p.o., per oral; PTZ, pentylenetetrazol; ROS, reactive oxygen species; SBP, systolic blood pressure; SOD, superoxide dismutase; STZ, streptozotocin; TST, tail suspension test. 


\subsection{Antidiabetic Effect}

The antidiabetic effect of $A$. calamus ethyl acetate fraction was evaluated in streptozotocin (STZ)-induced and diabetic (db/db) mice. Glucagon-like peptide-1 (GLP-1) levels, plasma insulin, "and related gene expression were evaluated. The fraction $(100 \mathrm{mg} / \mathrm{kg}$, intragastric (i.g.)) indicated a significant reduction in blood glucose levels. For in vitro, at the concentration of $12.5 \mu \mathrm{g} / \mathrm{mL}$, a significant increment in GLP-1 levels was found in the insulin-secreting L-cell culture medium [108]. The ethyl acetate radix fraction exhibited a significant effect on the HIT-T15 cell line and $\alpha$-glucosidase enzyme. The ethyl acetate fraction also enhanced insulin secretion in HIT-T15 cells and blocked the $\alpha$-glucosidase in vitro activity with $0.41 \mu \mathrm{g} / \mathrm{mL}$ of inhibitory concentration $\left(\mathrm{IC}_{50}\right)$ [109]."

\subsection{Anti-Obesity Effect}

The $\beta$-asarone compound isolated from the rhizome was investigated against high-fat diet (HFD)-induced obesity in animals. $\beta$-Asarone-treated adipose rats showed weight loss, but also inhibited metabolic transformations, as well as glucose intolerance, elevated cholesterol, and adipokine variance [143]. The in vitro investigation on the A. calamus aqueous extract showed lipid-lowering activity through inhibition of the pancreatic lipase percentage (28.73\%) [144].

\subsection{Antihypertensive Effect}

The antihypertensive effects of $A$. calamus were studied on their own, in isolation, and in combination with Gymnema sylvestre in the HFD-induced hypertension in rats. The HFD was given for 4 weeks, which significantly increased the average systolic blood pressure (SBP). At a $200 \mathrm{mg} / \mathrm{kg}$ dose, A. calamus in combination with G. sylvestre reduced the SBP and heart rate significantly. A. calamus with G. sylvestre exhibited synergistic effect as compared with individual herbs [145].

\subsection{Anti-Inflammatory and Immunomodulatory Effect}

The methanolic A. calamus rhizome extract $(12.5 \mu \mathrm{g} / \mathrm{mL})$ prevented the VCAP-1 and intercellular expression on the surface of mouse myeloid leukemia cells and murine endothelial cells, respectively [146]. In an in vitro anti-inflammatory study (Red blood cell membrane stabilization method), the A. calamus aqueous rhizome extract at the highest concentration of $10 \mathrm{mg} / \mathrm{mL}$ showed insignificant activity against hemolysis inhibition and the RBC membrane stabilization percentage [144]. Aqueous A. calamus leave extract was studied on $\mathrm{HaCaT}$ cells and restricted the characteristics of interleukin (IL)-8, IL-6 RNA protein levels alongside interferon regulatory factor 3 (IRF3) and nuclear factor kB (NF-kB) activation [147]. $\mathrm{N}$-hexane, butanolic, and aqueous fractions of $A$. calamus were evaluated against cyclooxygenase (COX) and lipoxygenase (LOX)-mediated eicosanoid production by arachidonic acid. The butanolic fraction inhibited the COX-mediated production of thromboxane B2 (TXB2) and lipoxygenase product 1 (LP1). Investigation of the underlying signaling pathways revealed that the butanolic fraction inhibited phospholipase C (PLC) pathway in platelets, presumably acting on protein kinase C (PKC) [148]. The essential oil isolated from A. calamus was evaluated by protein denaturation assay, where at the concentration level of $300 \mu \mathrm{g} / \mathrm{mL}, 69.56 \%$ of the inhibition level was observed [149].

\subsection{Antioxidant Effect}

The in vitro antioxidant activity of acetone, acetonitrile, alcoholic, and aqueous extracts of $A$. calamus rhizomes exhibited free radical scavenging activity on the $\left[2,2^{\prime}\right.$-azinobis (3-ethylbenzothiazoline6-sulphonic acid)] free radical scavenging activity assay (ABTS), the (1, 1-diphenyl-2-picrylhydrazyl) free radical scavenging activity assay (DPPH), and the ferric ion reducing antioxidant power assay (FRAP). Strong antioxidant effect was noticed in the acetone extract, followed by acetonitrile and methanol, while in the aqueous extract, poor antioxidant activity was found [150]. The aqueous extract exhibited superior antioxidant effects in metal ion chelation, lipid peroxidation (LPO), and DPPH assays [144,151]. The in vitro antioxidant activity of ethanol, hydro-ethanol, and aqueous whole plant extracts of 
A. calamus was investigated using FRAP, DPPH, nitric oxide, hydroxyl radical, reductive ability, and superoxide radical scavenging activity. The existence of phenolics and flavonoids in A. calamus are believed to contribute to the promising antioxidant effect. $\mathrm{IC}_{50}$ values of the ethanol extract were found to be $54.82,109.85,38.3,118.802 \mu \mathrm{g} / \mathrm{mL}$ for the scavenging activities of DPPH, hydroxyl radical, superoxide radical, and nitric oxide, respectively. The irreversible potential of the above results and the FRAP values of the extracts were found to augment in a concentration-dependent manner [152]. "Ethanol and hydro-alcoholic extracts of $A$. calamus roots and rhizomes were studied for antioxidant potential against DPPH compared with butylated hydroxyanisole (BHA) and silymarin. Ethanol and hydro-alcoholic extracts showed free radical scavenging activity of $59.13 \pm 18.95$ and $56.71 \pm 19.54$, respectively [153-155]. The essential oil isolated from $A$. calamus showed strong antioxidant efficacy against the $\beta$-carotene/linoleic acid bleaching test and DPPH free radicals [156]. The methanol extract of the A. calamus rhizome was evaluated against the free radical scavenging activity, and the reported $\mathrm{IC}_{50}$ value was $704 \mu \mathrm{g} / \mathrm{mL}$ [157]. The $\mathrm{IC}_{50}$ of the essential oil was $1.68 \mu \mathrm{g} / \mathrm{mL}$, which showed virtuous free radical scavenging activity in the DPPH test [149]."

\subsection{Anticonvulsant Effect}

The methanol extract shows anticonvulsant effects feasibly through potentiating the action of gamma-aminobutyric acid (GABA) pathway in the central nervous system [124]. When it comes to the purification of A. calamus rhizome in cow urine, it is advocated in the Ayurvedic pharmacopoeia of India (API) before its therapeutic use. The purified rhizome was investigated in a maximal electroshock (MES) seizure model, and phenytoin was used as the standard drug. The raw and processed rhizome $(11 \mathrm{mg} / \mathrm{kg}$, p.o.) exhibited notable anticonvulsant activity by minimizing the span of the tonic extensor period in rats, whereas the processed rhizome showed better therapeutic activity than when it was raw [158]. The calamus oil isolated from the $A$. calamus rhizome was evaluated at varying dose levels of 30, 100, and $300 \mathrm{mg} / \mathrm{kg}$, p.o., body weight (b.w.), against MES, pentylenetetrazol (PTZ), and minimal clonic seizure (MCS) models. The calamus oil was found to be neurotoxic at $300 \mathrm{mg} / \mathrm{kg}$, though it was effective in the MCS test at $6 \mathrm{~Hz}$. The protective index value of calamus oil was found to be 4.65 [125].

\subsection{Antidepressant Effect}

Interaction of the methanolic A. calamus rhizome extract with the adrenergic, dopaminergic, serotonergic, and GABAergic system was found responsible for the expression of antidepressant activity [128]. In another study, the methanolic A. calamus leave extract showed significant activity through a reduction in the immobility period in the TST and FST [129]. Through interaction with the adrenergic and dopaminergic system, the hydro-alcoholic extract was normalized to the over-activity of the hypothalamic pituitary adrenal (HPA) axis [131]. Sobers capsules (a herbo-mineral formulation containing A. calamus) were evaluated by tail suspension and forced swimming tests in mice. At the oral dose of $50 \mathrm{mg} / \mathrm{kg}$ for 14 days, capsules exhibited insignificant impact on locomotor activity, and caused antidepressant effects in experimental animals [159]. Tensarin (the traditional medicine of Nepal containing A. calamus) was evaluated for the anxiolytic effect in mice using the open field test (OFT), activity monitoring along with the passive avoidance test. At all three dose levels $(50,100$, $200 \mathrm{mg} / \mathrm{kg}$ ), Tensarin produced an anxiolytic effect in a dose-dependent way by an improvement in rearing, number of passages, and duration of the period employed by mice [160].

\subsection{Neuroprotective Effect}

The ethanolic extract was studied $(25,50$, and $100 \mathrm{mg} / \mathrm{kg}$ doses, oral and intraperitoneal routes) for learning and memory-enhancing activity. The subjects used consisted of male rates, through $Y$ maze and shuttle box tests models. The findings showed an increase in acquisition-recalling and spatial recognition data [161]. The ethanolic A. calamus rhizome extract $(0.5 \mathrm{~mL} / \mathrm{kg}$, i.p.) potentiated pentobarbitone-created sleep periods, which caused significant inhibition of conditioned avoidance response in rats and marked (40-60\%) protection against PTZ-induced convulsions, although it did 
not show any spontaneous motor activity and impact the aggressive or fighting behavior response in male rat pairs [162].

\subsection{Cardioprotective Effect}

The alcoholic A. calamus rhizome extract (100 and $200 \mathrm{mg} / \mathrm{kg}$ ) considerably attenuated isoproterenol-led cardiomyopathy in rats and showed a significant reduction in the heart/body weight ratio, level of serum calcineurin, serum nitric oxide, serum lactate dehydrogenase (LDH), and thiobarbituric acid reactive substances (TBARS) level. However, the level of the antioxidant enzyme was found increased at the $100 \mathrm{mg} / \mathrm{kg}$ extract dose level [163]. The crude extract and its fractions $(0.01-10 \mathrm{mg} / \mathrm{mL})$ were investigated in an isolated rabbit heart, which showed mild reduction in the force of forced vital capacity (FVC), hazard ratio (HR), and cystic fibrosis (CF), while the ethyl acetate extract exhibited complete suppression, and the n-hexane fraction showed the same effect on FVC and HR, but enhanced CF. The extract and its fractions exhibited controlled coronary vasodilator effect, interceded maybe by an endothelial-derived hyperpolarizing factor [164]. The cardioprotective potential of the whole plant's ethanolic extract (100 and $200 \mathrm{mg} / \mathrm{kg}$ ) reduced serum enzyme levels and shielded the myocardium from the lethal effect of DOX [141].

\subsection{Cytochrome Inhibitory Activities}

Cytochromes P450 (CYPs) are the prime enzymes that catalyze the oxidative metabolism of a wide variety of xenobiotics. It is known that 2,4,5-trimethoxycinnamic acid is the main metabolite of $\alpha$ or $\beta$ - asarone [165]. The metabolism rate of $\alpha$ - and $\beta$-asarone was shown to be directly proportional to the CYPs concentration in rat hepatocytes and liver microsomes $[166,167]$. CYP3A4 (CYP isoforms) has been reported for bioactivation of $\alpha$-asarone [168]. The hydro-alcoholic $A$. calamus extract and $\alpha$-asarone were evaluated by the CYPs-carbon monoxide complex method. The extract exhibited moderate potential interaction in CYP3A4 $\left(\mathrm{IC}_{50}=46.84 \mu \mathrm{g} / \mathrm{mL}\right)$ and CYP2D6 $\left(\mathrm{IC}_{50}=36.81 \mu \mathrm{g} / \mathrm{mL}\right)$, while $\alpha$-asarone showed higher interaction in CYP3A4 $\left(\mathrm{IC}_{50}=65.16 \mu \mathrm{g} / \mathrm{mL}\right)$ and CYP2D6 $\left(\mathrm{IC}_{50}=55.17 \mu \mathrm{g} / \mathrm{mL}\right)$ [169]. These outcomes indicated that both extracts and $\alpha$-asarone interacted quite well in drug metabolism and also had an inhibitory effect on CYP3A4 and CYP2D6. The drug-drug interaction effect of the $A$. calamus extract and its main chemical constituent ( $\alpha$ and $\beta$-asarone) needs to be studied in more CYPs isomers, like CYP2C9 and CYP2E1.

\subsection{Toxicity and Safety Concerns}

In acute and sub-acute toxicity of the hydro-alcoholic extract of $A$. calamus in rats, at the highest dose level of $10 \mathrm{gm} / \mathrm{kg}$, no severe changes were observed, and the lethal dose $\left(\mathrm{LD}_{50}\right)$ was found to be $5 \mathrm{~g} / \mathrm{kg}$ [170]. The petroleum ether extracts (obtained by cold rolling, water distillation, and Soxhlet extraction methods) of the A. calamus rhizome showed mild toxicity in two-day-old oriental fruit flies [171]. The ethanolic extract of the A. calamus rhizome at oral dosage of $175,550,1750$, and $5000 \mathrm{mg} / \mathrm{kg} \mathrm{b}$.w. was given for 14 days within an acute toxicity study, while at the dose level of $0,200,400$, and $600 \mathrm{mg} / \mathrm{kg}$, p.o., the extract was given for 90 days within a chronic toxicity study. At the doses of 1750 and $5000 \mathrm{mg} / \mathrm{kg}$, piloerection, tremors, and abdominal breathing were found for $30 \mathrm{~min}$ [172]. In that study, A. calamus was purified for $3 \mathrm{~h}$ in cow urine, decoction of Sphaeranthus indicus, and decoction of leaves of Mangifera indica, Eugenia jambolana, Feronia limonia, Citrus medica, and Aegle marmelos, followed by fomentation with Gandhodaka (decoction of six aromatic herbs) for $1 \mathrm{~h}$. The acute oral toxicity test of raw and purified A. calamus was performed in albino rats at $2000 \mathrm{mg} / \mathrm{kg}$ for 2 weeks. At the $2000 \mathrm{mg} / \mathrm{kg}$ dose, A. calamus did not produce any toxic symptoms within 14 days [173].

The $\beta$-asarone compound isolated from A. calamus was found to be carcinogenic and toxic [174]. The $\mathrm{LD}_{50}$ value of $\beta$-asarone by oral and intraperitoneal route was found to be 1010 and $184 \mathrm{mg} / \mathrm{kg}$, respectively, in mice and rats [175]. The $\mathrm{LD}_{50}$ of calamus oil was found to be $8.88 \mathrm{gm} / \mathrm{kg}$ b.w. [176], while in the calamus oil obtained from Jammu, India, the $\mathrm{LD}_{50}$ was $777 \mathrm{mg} / \mathrm{kg}$ b.w. [177]. Overall, 
several investigations have been carried out on A. calamus regarding its toxicity; however, no noticeable data on toxicity have been found so far.

\section{Clinical Reports}

A. calamus has also been clinically investigated as a monotherapy as well as in combination with other medicinal herbs in healthy subjects and sufferers of various metabolic and neurological ailments. Most clinical research has looked at the A. calamus effect on obesity, depression, neuroprotection, and cardiovascular disease [178-191]. The data obtained so far can be found in Table 5. Furthermore, a systematic review reveals that $A$. calamus (alone or in combination therapy) exhibits anti-obesity, antidepressant, and cardioprotective effects, as well as helps physical and mental performance. 
Table 5. Clinical claims of $A$. calamus in neurological and metabolic disorders

\begin{tabular}{|c|c|c|c|c|c|c|c|}
\hline $\begin{array}{l}\text { Formulations/Dosage forms } \\
\text { A. calamus }\end{array}$ & Subjects & Study Design & Intervention & Primary Endpoint & Outcome & Evidence Quality & Reference \\
\hline A. calamus rhizome powder & $\begin{array}{l}24 \text { patients of both sexes } \\
\text { with hyperlipidemia }\end{array}$ & $\begin{array}{l}\text { Randomized } \\
\text { single-blind } \\
\text { controlled study }\end{array}$ & $\begin{array}{l}500 \mathrm{mg} \text { twice daily after meal } \\
\text { for } 1 \text { month }\end{array}$ & $\begin{array}{l}\text { BMI, body perimeter, } \\
\text { skinfold depth }\end{array}$ & $\begin{array}{l}\text { Significant reduction in } \\
\text { skinfold depth, fatigue, } \\
\text { and excessive hunger }\end{array}$ & III & [178] \\
\hline $\begin{array}{l}\text { Davaie Loban capsules (A. calamus, } \\
\text { nut grass, incense, ginger, } \\
\text { and black pepper) }\end{array}$ & $\begin{array}{l}24 \text { patients of both } \\
\text { sexes with Alzheimer's } \\
\text { disease }\end{array}$ & $\begin{array}{l}\text { Double-blind } \\
\text { randomized clinical } \\
\text { study }\end{array}$ & $\begin{array}{l}500 \mathrm{mg} \text { capsule thrice daily for } \\
3 \text { months }\end{array}$ & $\begin{array}{l}\text { ADAS-cog and CDR-SOB } \\
\text { scores }\end{array}$ & $\begin{array}{l}\text { At } 4 \text { weeks and } 12 \text { weeks: } \\
\text { significant reduction in the } \\
\text { ADAS-cog and CDR-SOB scores }\end{array}$ & III & [179] \\
\hline $\begin{array}{l}\text { 70\% hydro-alcoholic extract of } \\
\text { A. calamus }\end{array}$ & $\begin{array}{l}33 \text { patients of both sexes } \\
(20 \text { male and } 13 \text { female) } \\
\text { with anxiety disorder }\end{array}$ & $\begin{array}{l}\text { Non-randomized, } \\
\text { open-label, single-arm } \\
\text { study }\end{array}$ & $\begin{array}{l}500 \mathrm{mg} \text { extract of one capsule } \\
\text { twice daily after meal for } \\
2 \text { months }\end{array}$ & BPRS score & $\begin{array}{l}\text { Significant reduction of anxiety } \\
\text { and stress-related disorder }\end{array}$ & III & [180] \\
\hline $\begin{array}{l}\text { Vachadi Churna (A. calamus, Cyperus } \\
\text { rotundus, Cedrus deodara, ginger, } \\
\text { Aconitum Heterophyllum, T. chebula })\end{array}$ & $\begin{array}{l}30 \text { obese patients of both } \\
\text { sexes aged } 14-50 \text { years }\end{array}$ & $\begin{array}{l}\text { Non-randomized, } \\
\text { open-label, } \\
\text { single-arm study }\end{array}$ & $\begin{array}{l}\text { 3g powder twice daily with } \\
\text { lukewarm water before meal } \\
\text { for } 1 \text { month }\end{array}$ & $\begin{array}{l}\text { BMI, girth measurements of } \\
\text { mid-thigh, abdomen, hip, chest }\end{array}$ & $\begin{array}{l}\text { Significant improvement in } \\
\text { extreme sleep, body heaviness, } \\
\text { fatigue, and excessive hunger }\end{array}$ & III & [181] \\
\hline $\begin{array}{l}\text { Guduchyadi Medhya Rasayana, } \\
\text { (A. calamus, Tinospora cordifolia, } \\
\text { Achyranthes aspera, Embelia ribes, } \\
\text { Convolvulus pluricaulis, T. chebula, } \\
\text { S. lappa, Asparagus racemosus, } \\
\text { cow ghee, and sugar) }\end{array}$ & $\begin{array}{l}138 \text { patients of both } \\
\text { sexes aged 55-75 years } \\
\text { with senile memory } \\
\text { impairment }\end{array}$ & $\begin{array}{l}\text { Randomized, } \\
\text { two-parallel-group } \\
\text { study }\end{array}$ & $\begin{array}{l}3 \mathrm{~g} \text { granule thrice daily after } \\
\text { meal for } 3 \text { months }\end{array}$ & $\begin{array}{l}\text { Mini-Mental State Examination, } \\
\text { BPRS score, and estimation of } \\
\text { serum acetylcholinesterase }\end{array}$ & $\begin{array}{l}\text { Significant improvement in } \\
\text { terms of recall memory, } \\
\text { cognitive impairment, amnesia, } \\
\text { concentration ability, } \\
\text { depression, and stress }\end{array}$ & III & [182] \\
\hline Dried aqueous extract of $A$. calamus & $\begin{array}{l}40 \text { healthy volunteers, } \\
\text { both sexes aged } 18-50 \\
\text { years with a } \\
\text { premedicant for } \\
\text { anesthesia }\end{array}$ & $\begin{array}{l}\text { Open-label randomized, } \\
\text { two- parallel-group } \\
\text { study }\end{array}$ & $\begin{array}{l}90 \text { min before anesthesia; } \\
\text { In the control group: } \\
0.2 \mathrm{mg} \text { intramuscular (IM) } \\
\text { glycopyrrolate and a } 0.2 \mathrm{mg} \text { IM } \\
50 \mathrm{mg} \text { tablet of promethazine } \\
\text { hydrochloride with water; } \\
\text { In the second group: } 0.2 \mathrm{mg} \text { IM } \\
\text { glycopyrrolate and } 100 \mathrm{mg} \\
\text { A. calamus extract }\end{array}$ & $\begin{array}{l}\text { Pulse rate, blood pressure, } \\
\text { respiratory rate, } \\
\text { body temperature }\end{array}$ & $\begin{array}{l}\text { The dried aqueous extract } \\
\text { exhibited anti-hyperthermic } \\
\text { and sedative effect without } \\
\text { producing } \\
\text { any respiratory depression }\end{array}$ & III & [183] \\
\hline $\begin{array}{l}\text { Shankhapushpyadi Ghana Vati } \\
\text { (A. calamus, C. pluricaulis, Bacopa } \\
\text { monnieri, T. cordifolia, C. fistula, } \\
\text { A. indica, S. lapa, Tribulus terrestris) }\end{array}$ & $\begin{array}{l}20 \text { hypertensive patients } \\
\text { of both sexes }\end{array}$ & $\begin{array}{l}\text { Randomized } \\
\text { single-blind controlled } \\
\text { study }\end{array}$ & $\begin{array}{l}1 \mathrm{~g} \text { twice daily after meal for } \\
2 \text { months }\end{array}$ & SBP and DBP & $\begin{array}{l}\text { Significant relief in raised SBP } \\
\text { and DBP }\end{array}$ & III & [184] \\
\hline $\begin{array}{l}\text { Brahmyadiyoga (A. calamus, Centella } \\
\text { asiatica, Rauvolfia serpentina, Saussurea } \\
\text { lappa, Nardostachys jatamansi) }\end{array}$ & $\begin{array}{l}10 \text { schizophrenia } \\
\text { patients of both sexes } \\
\text { aged } 18-40 \text { years }\end{array}$ & $\begin{array}{l}\text { Non-randomized, } \\
\text { open-label, single- } \\
\text { arm study }\end{array}$ & $\begin{array}{l}4 \text { tablets thrice daily for three } \\
\text { months after meal }\end{array}$ & Symptoms rating scale & $\begin{array}{l}\text { Significant effect as a brain } \\
\text { tonic, tranquillizer, hypnotic, } \\
\text { and sedative }\end{array}$ & III & [185] \\
\hline $\begin{array}{l}\text { Bala compound (A. calamus, } \\
\text { Emblica officinalis, E. ribes, T. cordifolia, } \\
\text { Piper longum, Glycyrhiza glabra, } \\
\text { C. rotundus, A. heterophyllum })\end{array}$ & $\begin{array}{l}24 \text { neonates, both sexes, } \\
2.5-3 \mathrm{~kg} \text { body weight }\end{array}$ & $\begin{array}{l}\text { Randomized } \\
\text { single-blind controlled } \\
\text { study }\end{array}$ & $\begin{array}{l}5 \text { oral drops twice daily for } \\
6 \text { months }\end{array}$ & $\begin{array}{l}\text { Change in serum } \\
\text { immunnoglobulins (IgG, IgM, } \\
\text { and IgA) levels }\end{array}$ & $\begin{array}{l}\text { Significant improvement in } \\
\text { immunoglobulin levels after } \\
6 \text { months }\end{array}$ & $\mathrm{Ib}$ & [186] \\
\hline $\begin{array}{l}\text { Vachadi Ghrita (A. calamus, } \\
\text { T. cordifolia, Hedychium spicatum, } \\
\text { C. pluricaulis, }, \text {. ribes, ginger, A. aspera, } \\
\text { T. chebula, and cow ghee) }\end{array}$ & $\begin{array}{l}90 \text { healthy individuals } \\
\text { of both sexes aged } 40-50 \\
\text { years for assessment } \\
\text { of cognition }\end{array}$ & $\begin{array}{l}\text { Non-randomized } \\
\text { positive-controlled } \\
\text { study }\end{array}$ & $\begin{array}{l}10 \mathrm{~g} \text { twice daily for } 1 \text { month } \\
\text { with lukewarm water }\end{array}$ & $\begin{array}{l}\text { Post Graduate Institute } \\
\text { Memory Scale (PGIMS) test }\end{array}$ & $\begin{array}{l}\text { Significant change in the mental } \\
\text { balance score, holding } \\
\text { of like and different pairs, } \\
\text { late-immediate memory, } \\
\text { and also improved digestion }\end{array}$ & III & [187] \\
\hline
\end{tabular}


Table 5. Cont

\begin{tabular}{|c|c|c|c|c|c|c|c|}
\hline $\begin{array}{l}\text { Formulations/Dosage forms } \\
\text { A. calamus }\end{array}$ & Subjects & Study Design & Intervention & Primary Endpoint & Outcome & Evidence Quality & Reference \\
\hline $\begin{array}{l}\text { Bramhi Vati (A. calamus, B. monnieri, } \\
\text { C. pluricaulis, Onosma bracteatum, } \\
\text { copper pyrite, iron pyrite, mercuric } \\
\text { sulphide, Piper nigrum, N. jatamansi) }\end{array}$ & $\begin{array}{l}68 \text { essential } \\
\text { hypertension patients of } \\
\text { both sexes } \\
\text { aged } 20-70 \text { years }\end{array}$ & $\begin{array}{l}\text { Randomized, } \\
\text { double-blind, } \\
\text { parallel-group } \\
\text { comparative study }\end{array}$ & $\begin{array}{l}500 \mathrm{mg} \text { tablets twice daily for } \\
1 \mathrm{month}\end{array}$ & $\begin{array}{l}\text { Hamilton anxiety rating scale, } \\
\text { SBP and DBP, and MAP }\end{array}$ & $\begin{array}{l}\text { Significant improvement in the } \\
\text { Hamilton anxiety rating scale, } \\
\text { SBP and DBP, and MAP }\end{array}$ & III & [188] \\
\hline $\begin{array}{l}\text { Tagaradi Yoga (A. calamus, } \\
\text { Valeriana wallichii, N. jatamansi) }\end{array}$ & $\begin{array}{l}24 \text { insomnia patients of } \\
\text { both sexes } \\
\text { aged } 18-75 \text { years }\end{array}$ & $\begin{array}{l}\text { Non-randomized } \\
\text { positive-controlled } \\
\text { study }\end{array}$ & $\begin{array}{l}500 \mathrm{mg} \text { hydro-alcoholic extract } \\
\text { capsule twice daily after meal } \\
\text { for } 15 \text { days }\end{array}$ & $\begin{array}{l}\text { Sleep duration, initiating time } \\
\text { of sleep, quality of sleep }\end{array}$ & $\begin{array}{l}\text { Significant improvement in } \\
\text { sleep duration, in the initiating } \\
\text { time of sleep, } \\
\text { and in quality of sleep }\end{array}$ & III & [189] \\
\hline Acorus calamus rhizome powder & $\begin{array}{l}20 \text { obese patients of both } \\
\text { sexes }\end{array}$ & $\begin{array}{l}\text { Randomized } \\
\text { single-blind study }\end{array}$ & $\begin{array}{l}250 \mathrm{mg} \text { rhizome powder twice } \\
\text { daily for } 1 \text { month }\end{array}$ & $\begin{array}{l}\text { Body weight, height according } \\
\text { to age, waist-hip ratio, and BMI }\end{array}$ & $\begin{array}{l}\text { Significant improvement in } \\
\text { extreme sleep, body heaviness, } \\
\text { fatigue, and excessive hunger }\end{array}$ & III & [190] \\
\hline Acorus calamus rhizome powder & $\begin{array}{l}45 \text { ischemic heart } \\
\text { disease patients }\end{array}$ & $\begin{array}{l}\text { Non-randomized } \\
\text { positive-controlled } \\
\text { study }\end{array}$ & $\begin{array}{l}3 \text { gm rhizome powder twice } \\
\text { daily for } 3 \text { months }\end{array}$ & ECG, serum cholesterol level & $\begin{array}{l}\text { Improvement of chest pain, } \\
\text { dyspnea on effort, reduction of } \\
\text { the body mass index, improved } \\
\text { ECG: reduced serum } \\
\text { cholesterol, reduced serum } \\
\text { LDL, and increased serum HDL }\end{array}$ & $\mathrm{Ib}$ & [191] \\
\hline
\end{tabular}




\section{Mechanistic Role}

The proposed mechanism of action of A. calamus in neurological and metabolic disorders includes a synergic integration of antioxidant defense, GABAergic transmission, brain stress hormones modulation, pro-inflammatory cytokines, leptin and resistin levels, adipocytes inhibition, calcium channel blocker effect, protein synthesis, oxidative stress, acetylcholinesterase (AChE) inhibition, and anti-dopaminergic properties. A compendium of mechanisms of action of A. calamus in neurological and metabolic protection is illustrated in Figure 6 and Table 6. A. calamus significantly affects fasting blood sugar, insulin resistance, $\mathrm{HbA1c}$, and the adipogenic transcription expression factor through various mechanisms, viz. antioxidant, anti-inflammatory, $\beta$-cells regeneration, improving insulin sensitivity, gluconeogenesis, nicotinamide adenine dinucleotide phosphate (NADPH) oxidase, and glucose transporter type 4 (GLUT-4)-mediated transport inhibition.

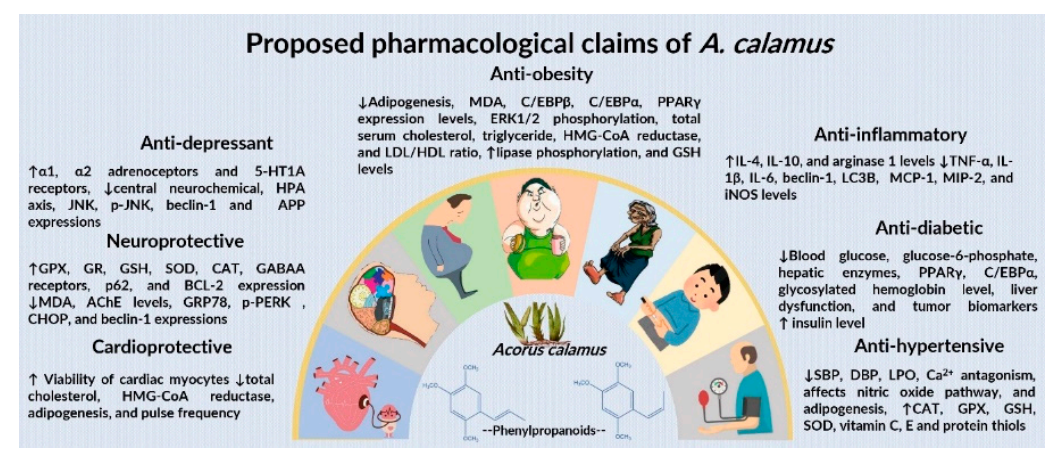

Figure 6. Illustration of role of $A$. calamus mechanisms in the treatment of neurological and metabolic disorders. AChE, acetylcholinesterase; APP, amyloid precursor protein; Bcl-2, B-cell lymphoma 2; CHOP, C/EBP homologous protein; CCAAT (cytosine-cytosine-adenosineadenosine-thymidine)-enhancer-binding protein homologous protein; C/EBP, CCAAT enhancer-binding protein; GABAA, $\gamma$-Aminobutyric acid type A; GRP78, 78-kDa glucose-regulated protein; HMG-CoA, 3-hydroxy-3-methylglutaryl coenzyme A; iNOS, inducible nitric oxide synthase; JNK, c-Jun $\mathrm{NH} 2$-terminal kinase; LC3b, microtubule-associated proteins 1A/1B light chain 3B; $\mathrm{MCP}$, modified citrus pectin; MDA, malondialdehyde; MIP, macrophage inflammatory protein; p-PERK, phospho-protein kinase RNA-like ER kinase; PPAR $\gamma$, peroxisome proliferator-activated receptor gamma; ERK1/2, extracellular signal-regulated protein kinase. 
Table 6. Mechanistic role of phytochemicals of A. calamus in the treatment of neurological and metabolic disorders.

\begin{tabular}{|c|c|c|c|c|c|}
\hline Study & Compound & Model & Increased Level & Decreased Level & References \\
\hline \multirow{4}{*}{ Anti-Parkinson } & \multirow{9}{*}{$\beta$-Asarone } & 6-OHDA parkinsonian & Bcl-2 expression & $\begin{array}{l}\text { GRP78, p-PERK, CHOP, and } \\
\text { Beclin- } 1 \text { expression }\end{array}$ & [192] \\
\hline & & 6-OHDA parkinsonian & - & $\begin{array}{l}\text { mRNA levels of GRP78 and CHOP } \\
\text { and p-IRE1and XBP1 }\end{array}$ & [193] \\
\hline & & Dopamine in the striatum & TH plasma concentrations & Striatal COMT levels & [194] \\
\hline & & 6-OHDA parkinsonian & $\begin{array}{l}\text { L-DOPA, DA, DOPAC, } \\
\text { and HVA levels }\end{array}$ & $\begin{array}{l}\text { P-gp, ZO- } 1 \text {, occludin, actin, } \\
\text { and claudin-5 }\end{array}$ & [195] \\
\hline \multirow{4}{*}{ Alzheimer's } & & $\begin{array}{l}\text { A } \beta 25-35 \text {-induced } \\
\text { inflammation }\end{array}$ & Bcl-2 level & $\begin{array}{l}\text { TNF- } \alpha \text {, IL- } 1 \beta, \text { IL-6, Beclin- } 1 \text {, } \\
\text { and LC3B level }\end{array}$ & [196] \\
\hline & & NG108 cells & - & $\begin{array}{l}\text { Upregulated SYP and } \\
\text { GluR1 expression }\end{array}$ & [197] \\
\hline & & PC12 cells & - & $\begin{array}{l}\mathrm{A} \beta \text {-induced JNK activation, } \mathrm{Bcl}-\mathrm{w} \\
\text { and } \mathrm{Bcl}-\mathrm{xL} \text { levels, cytochrome c } \\
\text { release, and caspase- } 3 \text { activation }\end{array}$ & [198] \\
\hline & & $\mathrm{A} \beta$-induced cytotoxicity & $\begin{array}{l}\text { Cell viability, p-Akt and } \\
\text { p-mTOR }\end{array}$ & NSE levels, Beclin-1 expression & [199] \\
\hline \multirow{4}{*}{ Neuroprotective } & & Pb-induced impairments & $\begin{array}{l}\text { NR2B protein expression } \\
\text { along with Arc/Arg3.1 } \\
\text { and Wnt7a mRNA levels }\end{array}$ & - & [200] \\
\hline & $\beta$-Asarone, eugenol & Scopolamine-induced & $\begin{array}{l}\text { Improvement of neuron } \\
\text { organelles and } \\
\text { synaptic structure }\end{array}$ & APP expression & [201] \\
\hline & Neotatarine & MTT reduction assay & - & A $\beta 25-35-$ induced PC12 cell death & [202] \\
\hline & $\beta$-asarone, paeonol & MCAo model & $\begin{array}{l}\text { Cholecystokinin and } \\
\text { NF-KB signaling }\end{array}$ & TNF- $\alpha$, IL- $1 \beta$, IL- 6 production & [203] \\
\hline
\end{tabular}


Table 6. Cont.

\begin{tabular}{|c|c|c|c|c|c|}
\hline Study & Compound & Model & Increased Level & Decreased Level & References \\
\hline \multirow{6}{*}{ Neuroprotective } & \multirow{2}{*}{$\beta$-Asarone } & Cultured rat astrocytes & $\begin{array}{l}\text { NGF, BDNF, and GDNF } \\
\text { expression }\end{array}$ & - & [204] \\
\hline & & SN4741 cells & p62, Bcl-2 expression & $\begin{array}{l}\text { JNK, p-JNK and Beclin-1 } \\
\text { expressions }\end{array}$ & [205] \\
\hline & Tatarinolactone & hSERT-HEK293 cell line & - & SERTs activity & [206] \\
\hline & \multirow{4}{*}{$\beta$-Asarone } & RSC96 Schwann cells & $\begin{array}{l}\text { GDNF, BDNF, and CNTF } \\
\text { expression }\end{array}$ & - & [207] \\
\hline & & $\mathrm{A} \beta$-induced & $\begin{array}{l}\text { p-mTOR and p62 } \\
\text { expression }\end{array}$ & $\begin{array}{l}\text { AChE and } \mathrm{A} \beta_{42} \text { levels, p-Akt, } \\
\text { Beclin-1, and LC3B expression, APP } \\
\text { mRNA and Beclin- } 1 \text { mRNA levels }\end{array}$ & [208] \\
\hline & & $\mathrm{A} \beta 1-42$-induced injury & - & $\begin{array}{l}\text { GFAP, } \mathrm{AQP}_{4}, \mathrm{IL}-1 \beta \text {, and TNF- } \alpha \\
\text { expression }\end{array}$ & [209] \\
\hline \multirow[b]{2}{*}{ Anti-depression } & & $\begin{array}{l}\text { Chronic unpredictable } \\
\text { mild stress }\end{array}$ & BDNF expression & Blocked ERK1/2-CREB signaling & [210] \\
\hline & $\alpha$-Asarone & $\begin{array}{l}\text { Noradrenergic and } \\
\text { serotonergic } \\
\text { neuromodulators in TST }\end{array}$ & $\begin{array}{l}\alpha_{1} \text { and } \alpha_{2} \text { adrenoceptors } \\
\text { and } 5-\mathrm{HT}_{1 \mathrm{~A}} \text { receptors }\end{array}$ & - & [211] \\
\hline $\begin{array}{l}\text { Anticonvulsant and } \\
\text { sedative }\end{array}$ & Eudesmin & MES and PTZ & $\begin{array}{l}\text { GABA contents, } \\
\text { expressions of GAD65, } \\
\text { GABAA, and Bcl-2 }\end{array}$ & $\begin{array}{l}\text { Glu contents and ratio of } \\
\text { Glu/GABA, caspase-3 }\end{array}$ & [212] \\
\hline Anti-anxiety & \multirow{3}{*}{$\alpha$-Asarone } & BLA or CFA-induced & $\begin{array}{l}\text { Down-regulation of } \\
\text { GABA }_{A} \text { receptors }\end{array}$ & $\begin{array}{l}\text { Up-regulation of GluR1-containing } \\
\text { AMPA, NMDA receptors }\end{array}$ & [213] \\
\hline \multirow{3}{*}{ Anti-epilepsy } & & Temporal lobe epilepsy & $\begin{array}{l}\text { Levels of GABA, GAD67, } \\
\text { and GABAAR-mRNA } \\
\text { expression }\end{array}$ & GABA-T & [214] \\
\hline & & Mitral cells & $\begin{array}{l}\text { Down-regulation of } \\
\mathrm{GABA}_{\mathrm{A}} \text { receptors }\end{array}$ & $\mathrm{Na}^{+}$channel blockade & [215] \\
\hline & $\beta$-Asarone & KA-induced & GABA & Glu & [216] \\
\hline
\end{tabular}


Table 6. Cont

\begin{tabular}{|c|c|c|c|c|c|}
\hline Study & Compound & Model & Increased Level & Decreased Level & References \\
\hline Anti-inflammatory & $\alpha$-Asarone & Spinal cord injury & $\begin{array}{l}\text { IL-4, IL-10, and arginase } \\
1 \text { levels }\end{array}$ & $\begin{array}{l}\text { TNF- } \alpha \text {, IL-1 } \beta, \text { IL-6, MCP-1, MIP-2, } \\
\text { iNOS levels }\end{array}$ & [217] \\
\hline Cytoprotective & \multirow{5}{*}{$\beta$-Asarone } & $\begin{array}{l}\text { tBHP-induced } \\
\text { astrocyte injury }\end{array}$ & $\begin{array}{l}\text { GST, GCLM, GCLC, } \\
\text { NQO1, Akt } \\
\text { phosphorylation }\end{array}$ & - & [218] \\
\hline Cardioprotective & & $\begin{array}{l}\text { Cultured neonate rat } \\
\text { cardiac myocytes }\end{array}$ & $\begin{array}{l}\text { Viability of cardiac } \\
\text { myocytes }\end{array}$ & Pulse frequency & [219] \\
\hline Arteriosclerosis & & ECV304 cell strain & $\begin{array}{l}\text { Apoptotic rate of } \\
\text { ECV304 cells }\end{array}$ & $\begin{array}{l}\text { Apoptotic rate of MMP, stabilized } \\
\text { MMP and VSMC proliferation }\end{array}$ & [220] \\
\hline Anti-adipogenic & & 3T3-L1 preadipocytes & - & $\begin{array}{l}\mathrm{C} / \mathrm{EBP} \beta, \mathrm{C} / \mathrm{EBP} \alpha, \text { and } \mathrm{PPAR} \gamma \\
\text { expression levels, ERK } 1 / 2 \\
\text { phosphorylation }\end{array}$ & {$[89]$} \\
\hline Antioxidant & & Cerebral artery occlusion & Antioxidant activity & $\begin{array}{l}\text { Focal cerebral ischemic/ } \\
\text { reperfusion injury }\end{array}$ & [221] \\
\hline \multirow[b]{2}{*}{ Anti-diabetic } & $\begin{array}{l}\alpha \text {-Asarone }+\beta \text {-asarone }+ \\
\text { metformin } \mathrm{HCl}\end{array}$ & STZ-induced & Insulin level & $\begin{array}{l}\text { Glucose, glycosylated hemoglobin } \\
\text { level, liver dysfunction, and tumor } \\
\text { biomarkers }\end{array}$ & [222] \\
\hline & Asarone & 3T3-L1 preadipocytes & $\begin{array}{l}\text { Hormone-sensitive lipase } \\
\text { phosphorylation }\end{array}$ & $\begin{array}{l}\text { Intracellular triglyceride levels, } \\
\text { down-regulation of PPAR } \gamma \\
\text { and } C / E B P \alpha\end{array}$ & [223] \\
\hline
\end{tabular}

6-OHDA, 6-hydroxydopamine; Ox-LDL, oxidized low-density lipoprotein; BDNF, brain-derived neurotrophic factor; NGF, nerve growth factor; GDNF, glial derived neurotrophic factor; SERTs, serotonin transporters; MCAo, middle cerebral artery occlusion; A $\beta, \beta$-amyloid; NSE, neuron specific enolase; AMPA, $\alpha$-amino-3-hydroxy-5-methyl-4-isoxazolepropionic acid; NMDA, NR2A-containing N-methyl-D-aspartate; $\mathrm{GABA}_{\mathrm{A}}, \gamma$-aminobutyric acid A; BLA, basolateral amygdala; CFA, complete Freund's adjuvant; CNTF, ciliary neurotrophic factor; COMT, catechol-O-methyltransferase; TH, tyrosine hydroxylase; DA, dopamine; DOPAC, 3,4-dihydroxyphenylacetic acid; HVA, homovanillic acid; P-gp, P-glycoprotein; ZO-1, zonula occludens-1; SYP, synaptophysin; GluR1, glutamatergic receptor 1; GABA-T, GABA transaminase; TST, tail suspension test; KA, kainic acid; MCP-1, monocyte chemoattractant protein 1; MIP-2, macrophage inflammatory protein 2; iNOS, inducible nitric oxide synthase; GST, glutathione S-transferase; GCLM, glutamate-cysteine ligase modulatory subunit; GCLC, glutamate-cysteine ligase catalytic subunit; NQO1, NAD(P)H quinone oxidoreductase; GFAP, glial fibrillary acidic protein; AQP, aquaporin; VSMC, vascular smooth muscle cells; MMP, mitochondrial membrane potential; C/EBP, CCAAT enhancer-binding protein; PPAR $\gamma$, peroxisome proliferator-activated receptor gamma; ERK1/2, extracellular signal-regulated MMP, mitochondrial membrane potential; C/EBP, CCAAT enhancer-binding protein; PPAR $\gamma$, peroxisome proliferator-activated receptor gamma; ERK1/2, extracellular signal-regulated
protein kinase; XBP1, x-box binding protein; IRE1, inositol-requiring enzyme 1; A $\beta 1-42$, amyloid $\beta$ peptide; mTOR, mammalian target of rapamycin; MTT, 3-(4,5-dimethythiazol-. 2-yl)-2,5-diphenyl tetrazolium bromide; CREB, cAMP response element-binding protein; GABAAR, gamma-aminobutyric acid type-A receptor, tBHP, t-butyl hydroperoxide. 
The antihypertensive effect of $A$. calamus may be explained by $\mathrm{Ca}^{2+}$ antagonists that affect the nitric oxide pathway. The chemical constituents of $A$. calamus upregulate the antioxidant effect, suppress pro-inflammatory cytokines, and act as detoxifying enzymes through the NF- $\mathrm{kB}$ and nuclear factor erythroid 2-related factor 2 (Nrf2) signaling pathways. The Nrf2 pathway may be activated by phenylpropanoids, sesquiterpenoids, and monoterpenes by interaction of active phytoconstituents with nitric oxide derivatives react with thiol groups between KEAP1 and Nrf2, along with Nrf2 phosphorylation. "When Nrf2 is released from the Kelch-like erythroid-derived CNC (cap'n'collar) homology protein (ECH)-associated protein 1 (KEAP1), it transfers into the nucleus, where it induces the genes encoding protein expression impenetrable in glutathione (GSH) synthesis, antioxidant, and detoxifying phase 2 enzymes. Oxidative stress and ligands for tumor necrosis factor receptors (TNFRs) and toll-like receptors (TLRs) activate upstream Ik-B kinases (IKKs), ensuing phosphorylation of IkB that is generally bound to the inactive NF-kB dimer in the cytoplasm. After that, IkB is targeted for proteasomal degradation and NF-kB, then it moves into the nucleus where it induces inflammatory cytokine expression in addition to the genes encoding proteins like superoxide dismutase (SOD) 2 and $\mathrm{B}$ cell chronic lymphocytic leukemia (CLL)/lymphoma 2 (Bcl2) involved in adaptive stress response (Figure 7). The bioactive molecules of A. calamus can inhibit NF-kB in inflammatory immune cells, while other phytoconstituents may activate NF-kB in neuronal cells to improve stress resistance." A. calamus phytoconstituents regulate NF-kB, LOX, and COX-2 activity. These compounds dose-dependently suppress the production of inflammatory factors like NO, TNF- $\alpha$, IL-6, IL-1 $\beta$, and JNK signaling, acting as anti-inflammatory agents. In addition, it was also noted that the inflammation induced by various chemicals was inhibited by bioactive constituents through suppression of IkB/NF-kB and JNK/AP-1 signaling pathways. Thus, over several studies, it has been reported that asarone compounds have a potential against neurodegenerative diseases.

PPAR gene and C/EBP are involved in the differentiation process. PPAR- $\delta$ and PPAR- $\gamma$ promote adipogenesis. In the same way, amino acids and glucose react with C/EBP- $\delta$ and C/EBP- $\beta$. If low levels of glucose induce gadd153, the inactive dimer is formed, with C/EBP- $\beta$ inhibiting the progress of adipocyte development. C/EBP delta activates C/EBP- $\alpha$. This is mainly involved in the formation of mature adipocytes and lipid accumulation in adipose tissue. In 3T3-L1 preadipocytes, $\alpha$-asarone and $\beta$-asarone inhibited adipocyte differentiation and reduced the intracellular lipid accumulation, and also decreased the expression levels of adipogenic transcription factors (PPAR $\gamma$ and C/EBP $\alpha$ ). These phytochemicals significantly promoted adenosine monophosphate-activated protein kinase (AMPK), which is known to suppress adipogenesis. It was also found that pretreatment with $\alpha$-asarone and $\beta$-asarone, a typical inhibitor of AMPK, attenuated the inhibitory effect of asarone on AMPK phosphorylation. The asarone-induced AMPK activation leads to a decrease in adipogenic transcription factor expression, and suppresses adipogenesis. 


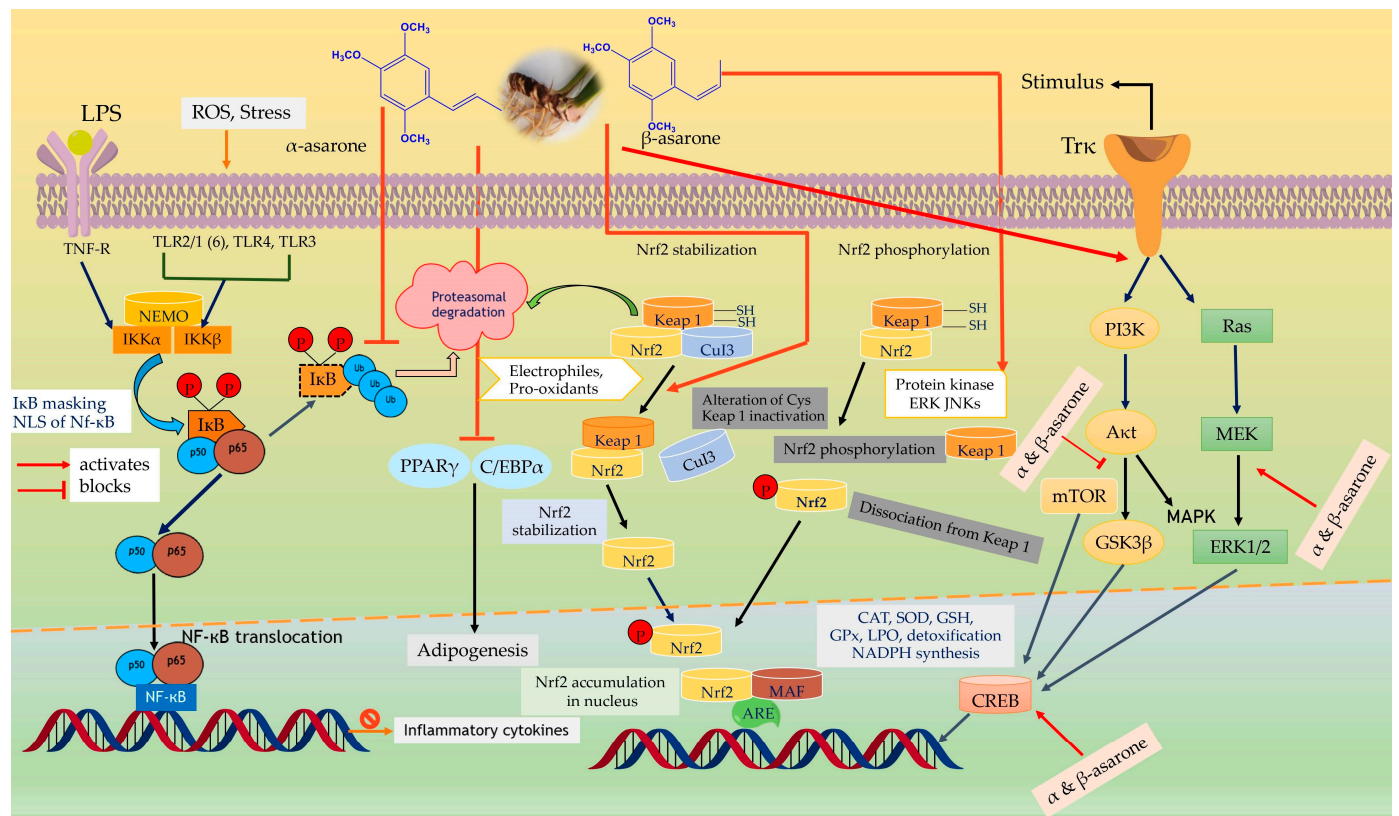

Figure 7. The role of the Nrf-2, NF-кB, PI3K/AKT, Ras/MAPK, and PPAR $\gamma$ signaling pathways as affected by phytoconstituents of Acorus calamus to upregulate antioxidant, neuroprotective, detoxifying enzymes and suppress inflammation. Ub, ubiquitin; NEMO, NF-kB essential modulator; ARE, antioxidant response element; Maf, musculoaponeurotic fibrosarcoma oncogene homolog; NLS, nuclear localization signal; CAT, catalase; GPX, glutathione peroxidase; Trk, tyrosine kinase receptor; LPS, lipopolysaccharide; TLRs, toll-like receptors; PI3K, phosphatidylinsoitol-3-kinase; MAPK, mitogen-activated protein kinase; mTOR, mammalian target of rapamycin; ERK, extracellular signal-regulated kinases; Nrf2, nuclear factor e2-related factor 2; Keap-1, kelch-like ECH-associated protein-1; MEK, mitogen-activated protein kinase; JNK, c-Jun N-terminal kinase;NADPH, nicotinamide adenine dinucleotide phosphate; NF- $\mathrm{B}$, nuclear factor-kappa B; IkB, inhibitor of kB; IKK, inhibitor of $\mathrm{kB}$ kinases.

\section{Perspectives and Future Directions}

The present review provides a plethora of information apropos ethnomedicinal uses, marketed formulations, geographical distribution, chemical constituents, pharmacological activities of crude, n-hexane, ethyl acetate, methanolic, ethanolic, hydro-alcoholic, aqueous extracts along with pure compounds, and clinical trials related to $A$. calamus.

Investigations on extracts and compounds of $A$. calamus suggested antidiabetic, anti-obesity, antihypertensive, anti-inflammatory, antioxidant, anticonvulsant, antidepressant, neuroprotective, and cardioprotective potentials with distinct underlying signaling pathways. The biological potential and mechanisms of action of some of the chemical constituents ( $\alpha$-asarone, $\beta$-asarone, eugenol) are known. However, other compounds need to be scientifically explored for their bioactivities and molecular modes of action, which could provide a lead for further development into therapeutics. More systematic, well-designed, and multi-center clinical studies are warranted to evaluate standardized extracts of $A$. calamus therapeutically and to identify the pharmacokinetic-dynamic roles of pharmacologically active biomolecules. There is scarce data from experimental and clinical reports on hypertension, diabetes, and atherosclerosis, and less supporting evidence is available on the use of $A$. calamus to treat hypertension and diabetes. Based on the available data, it is suggested that this plant could be used as an adjuvant to the established targeted drugs for neurological and metabolic disorders.

In 1974, United States food \& drug administration (USFDA) banned A. calamus due to its carcinogenic effects following animal studies. They reported $\beta$-asarone as a carcinogenic agent, but the study was conducted on the calamus oil which consists of $\beta$-asarone in about $80 \%$, while its different genotype in Europe and India contains $\beta$-asarone in lower concentrations. A. calamus cultivated 
in various geographical regions may have different chemical compositions along with therapeutic properties challenging quality control, toxicity, and safety concerns of A. calamus. In addition, the heavy metal, mycotoxin, and pesticide concentrations are required to be addressed in all toxicity studies.

\section{Conclusions}

Compelling in vitro, in vivo and clinical evidence suggests that the potential role of $A$. calamus rhizomes for modulating metabolic and neurological disorders could be due to their richness in several classes of active phytoconstituents. The predominant compounds present in rhizomes and leaves responsible for expression of potent bioactivities include $\alpha$-asarone, $\beta$-asarone, eugenol, and calamine. The present report is expected to fill the gaps in the existing knowledge and could provide a lead for researchers working in the areas of phytomedicine, ethnopharmacology, and clinical research.

Author Contributions: R.S. and V.S. conceived the idea and wrote the manuscript. D.S.G., K.K., E.N., and N.M. edited and proofread the document. The entire team approved the submission of the final manuscript. All authors have read and agreed to the published version of the manuscript.

Funding: This paper was supported by the UHK Excellence project.

Acknowledgments: The authors express their sincere gratitude to Bharat Ratna Mahamana Pandit Madan Mohan Malviya, the founder of the Banaras Hindu University, Varanasi, for his services to humanity, great vision, and blessings. This work was also supported by University of Hradec Kralove (Faculty of Science, VT2019-2021) [KK, EN].

Conflicts of Interest: The authors declare no conflict of interest.

\section{References}

1. World Health Report. Available online: https://www.who.int/whr/2001/media_centre/press_release/en/ (accessed on 4 October 2019).

2. Toniolo, A.; Cassani, G.; Puggioni, A.; Rossi, A.; Colombo, A.; Onodera, T.; Ferrannini, E. The diabetes pandemic and associated infections: Suggestions for clinical microbiology. Rev. Med. Microbiol. 2019, 30, 1-17. [CrossRef]

3. Younossi, Z.M. Non-alcoholic fatty liver disease-A global public health perspective. J. Hepatol. 2019, 70, 531-544. [CrossRef]

4. Després, J.P. Is visceral obesity the cause of the metabolic syndrome. Ann. Med. 2006, 38, 52-63. [CrossRef]

5. Farooqui, A.A.; Farooqui, T.; Panza, F.; Frisardi, V. Metabolic syndrome as a risk factor for neurological disorders. Cell. Mol. Life Sci. 2012, 69, 741-762. [CrossRef]

6. Tilg, H.; Hotamisligil, G.S. Nonalcoholic fatty liver disease: Cytokine-adipokine interplay and regulation of insulin resistance. Gastroenterology 2006, 131, 934-945. [CrossRef] [PubMed]

7. Suzanne, M.; Tong, M. Brain metabolic dysfunction at the core of Alzheimer's disease. Biochem. Pharmacol. 2014, 88, 548-559.

8. Quraishi, A.; Mehar, S.; Sahu, D.; Jadhav, S.K. In vitro mid-term conservation of Acorus calamus L. via cold storage of encapsulated microrhizome. Braz. Arch. Biol. Technol. 2017, 60, 1-9. [CrossRef]

9. Balakumbahan, R.; Rajamani, K.; Kumanan, K. Acorus calamus: An overview. J. Med. Plant Res. 2010, 4, $2740-2745$.

10. Sharma, V.; Singh, I.; Chaudhary, P. Acorus calamus (The Healing Plant): A review on its medicinal potential, micropropagation and conservation. Nat. Prod. Res. 2014, 28, 1454-1466. [CrossRef]

11. Singh, R.; Sharma, P.K.; Malviya, R. Pharmacological properties and ayurvedic value of Indian buch plant (Acorus calamus): A short review. Adv. Biol. Res. 2011, 5, 145-154.

12. Global Biodiversity Information Facility. Available online: https://www.gbif.org/ (accessed on 10 February 2020).

13. Kingston, C.; Jeeva, S.; Jeeva, G.M.; Kiruba, S.; Mishra, B.P.; Kannan, D. Indigenous knowledge of using medicinal plants in treating skin diseases in Kanyakumari district, Southern India. Indian J. Tradit. Knowl. 2009, 8, 196-200.

14. Pradhan, B.K.; Badola,H.K. Ethnomedicinal plant use by Lepcha tribe of Dzongu valley, bordering Khangchendzonga Biosphere Reserve, in north Sikkim India. J. Ethnobiol. Ethnomed. 2008, 4, 1-18. [CrossRef] [PubMed]

15. Sharma, P.K.; Chauhan, N.S.; Lal, B. Observations on the traditional phytotherapy among the inhabitants of Parvati valley in western Himalaya, India. J. Ethnopharmacol. 2004, 92, 167-176. [CrossRef] [PubMed] 
16. Dwivedi, S.N.; Dwivedi, S.; Patel, P.C. Medicinal plants used by the tribal and rural people of Satna district, Madhya Pradesh for the treatment of gastrointestinal diseases and disorders. Nat. Prod. Rad. 2006, 5, 60-63.

17. Usher, G. Spilanthes Acmella, a Dictionary of Plants Used by Man; CBS Publishers and Distributers: New Delhi, India, 1984; p. 38.

18. Ghosh, A. Ethnomedicinal plants used in West Rarrh region of West Bengal. Nat. Prod. Rad. 2008, 7, 461-465.

19. Natarajan, B.; Paulsen, B.S.; Korneliussen, V. An ethnopharmacological study from Kulu District, Himachal Pradesh, India: Traditional knowledge compared with modern biological science. Pharm. Biol. 2000, 38, 129-138. [CrossRef]

20. Nisha, M.C.; Rajeshkumar, S. Survey of crude drugs from Coimbatore city. Indian J. Nat. Prod. Resour. 2010, 1, 376-383.

21. Ragupathy, S.; Steven, N.G.; Maruthakkutti, M.; Velusamy, B.; Ul-Huda, M.M. Consensus of the 'Malasars' traditional aboriginal knowledge of medicinal plants in the Velliangiri holy hills, India. J. Ethnobiol. Ethnomed. 2008, 4, 8-16. [CrossRef]

22. Tomar, A. Folk medicinal uses of plant roots from Meerut district, Uttar Pradesh. Indian J. Tradit. Knowl. 2009, 8, 298-301.

23. Rajith, N.P.; Ramachandran, V.S. Ethnomedicines of Kurichyas, Kannur district, Western Ghats, Kerala. Indian J. Nat. Prod. Resour. 2010, 1, 249-253.

24. Barbhuiya, A.R.; Sharma, G.D.; Arunachalam, A.; Deb, S. Diversity and conservation of medicinal plants in Barak valley, Northeast India. Indian J. Tradit. Knowl. 2009, 8, 169-175.

25. Kadel, C.; Jain, A.K. Folklore claims on snakebite among some tribal communities of Central India. Indian J. Tradit. Knowl. 2008, 7, 296-299.

26. Boktapa, N.R.; Sharma, A.K. Wild medicinal plants used by local communities of Manali, Himachal Pradesh, India. Ethnobot. Leafl. 2010, 3, 259-267.

27. Kingston, C.; Nisha, B.S.; Kiruba, S.; Jeeva, S. Ethnomedicinal plants used by indigenous community in a traditional healthcare system. Ethnobot. Leafl. 2007, 11, 32-37.

28. Jain, A.; Roshnibala, S.; Kanjilal, P.B.; Singh, R.S.; Singh, H.B. Aquatic/semi-aquatic plants used in herbal remedies in the wetlands of Manipur, Northeastern India. Indian J. Tradit. Knowl. 2007, 6, 346-351.

29. Yabesh, J.M.; Prabhu, S.; Vijayakumar, S. An ethnobotanical study of medicinal plants used by traditional healers in silent valley of Kerala, India. J. Ethnopharmacol. 2014, 154, 774-789. [CrossRef]

30. Sher, Z.; Khan, Z.; Hussain, F. Ethnobotanical studies of some plants of Chagharzai valley, district Buner, Pakistan. Pak. J. Bot. 2011, 43, 1445-1452.

31. Poonam, K.; Singh, G.S. Ethnobotanical study of medicinal plants used by the Taungya community in Terai Arc Landscape, India. J. Ethnopharmacol. 2009, 123, 167-176. [CrossRef]

32. Shrestha, P.M.; Dhillion, S.S. Medicinal plant diversity and use in the highlands of Dolakha district Nepal. J. Ethnopharmacol. 2003, 86, 81-96. [CrossRef]

33. Khatun, M.A.; Harun-Or-Rashid, M.; Rahmatullah, M. Scientific validation of eight medicinal plants used in traditional medicinal systems of Malaysia: A review. Am. Eurasian J. Sustain. Agric. 2011, 5, 67-75.

34. Dastur, J.F. Medicinal Plants of India and Pakistan; D. B. Taraporevala Sons and Co. Ltd: Bombay, India, $1951 ;$ p. 12.

35. Satyavati, G.V.; Raina, M.K.; Sharmal, M. Medicinal Plants of India; Indian Council of Medical Research: New Delhi, India, 1976; Volume I, pp. 14-16.

36. Jain, S.K. Medicinal Plants; National Book Trust: New Delhi, India, 1968.

37. Malhi, B.S.; Trivedi, V.P. Vegetable antifertility drugs of India. Q. J. Crude Drug Res. 1972, 12, $19-22$.

38. Singh, M.P.; Malla, S.B.; Rajbhandari, S.B.; Manandhar, A. Medicinal plants of Nepal retrospect's and prospects. Econ. Bot. 1979, 33, 185-198. [CrossRef]

39. Kirtikar, K.R.; Basu, B.D. Indian Medicinal Plants; M/S. Bishen Singh Mahendra Pal Singh: Dehradun, India, 1975; Volume IV.

40. Lama, S.; Santra, S.C. Development of Tibetan plant medicine. Sci. Cult. 1979, 45, 262-265. [PubMed]

41. Burang, T. Cancer therapy of Tibetan healers. Comp. Med. East West 1979, 7, 294-296. [CrossRef] [PubMed]

42. Wallnofer, H.; Rottauscher, A. Chinese Folk Medicine and Acupuncture; Bell Publishing Co, Inc: New York, NY, USA, 1965.

43. Agarwal, S.L.; Dandiya, P.C.; Singh, K.P.; Arora, R.B. A note on the preliminary studies of certain pharmacological actions of Acorus calamus. J. Am. Pharm. Assoc. 1956, 45, 655-656. [CrossRef]

44. Duke, J.A.; Ayensu, E.S. Medicinal Plants of China; Reference Publications, Inc: Algonac, MI, USA, 1985. 
45. Perry, L.M.; Metzger, J. Medicinal Plants of East and Southeast Asia; MIT Press: Cambridge, UK, 1980.

46. Boissya, C.L.; Majumder, R. Some folklore claims from the Brahmaputra Valley (Assam). Ethnomedicine 1980, 6, 139-145.

47. Dragendorff, G. Die Heilpflanzen der Verschie Denen Volker und Zeiten; F. Enke: Stuttgart, Germany, 1898.

48. Li, H.L. Hallucinogenic plants in Chinese herbals. Harv. Univ. Bot. Mus. Leafl. 1977, 25, 161-177.

49. Shih-Chen, L. Chinese Medicinal Herbs; Georgetown Press: San Francisco, CA, USA, 1973.

50. Hirschhorn, H.H. Botanical remedies of the former Dutch East Indies (Indonesia) I: Eumycetes, Pteridophyta, Gymnospermae, Angiospermae (Monocotyledones only). J. Ethnopharmacol. 1983, 7, 123-156. [CrossRef]

51. Wren, R.C. Potter's New Cyclopaedia of Botanical Drugs and Preparations; Sir Isaac Pitman and Sons, Ltd: London, UK, 1956.

52. Grieve, M. A Modern Herbal; Dover Publications, Inc: New York, NY, USA, 1971; Volume II.

53. Wheelwright, E.G. Medicinal Plants and Their Stor; Dover Publications, Inc: New York, NY, USA, 1974.

54. Moerman, D.E. Geraniums for the Iroquois; Reference Publications, Inc: Algonac, MI, USA, 1981.

55. Jochle, W. Menses-inducing drugs: Their role in antique, medieval and renaissance gynecology and birth control. Contraception 1974, 10, 425-439. [CrossRef]

56. Watt, J.M.; Breyer-Brandwijk, M.G. The Medicinal and Poisonous Plants of Southern and Eastern Africa; E. \& S. Livingstone Ltd.: London, UK, 1962.

57. Kantor, W. Quack abortifacients and declining birth rate. Therap. Monatsh. 1916, 30, 561-568.

58. Herrmann, G. Therapy with medicinal plants in present medicine. Med. Monatsschr. Pharm. 1956, 10, 79.

59. Burkill, I.H. Dictionary of the Economic Products of the Malay Peninsula; Ministry of Agriculture and Cooperatives: Kuala Lumpur, Malaysia, 1966; Volume 1.

60. Motley, T.J. The Ethnobotany of Sweet Flag, Acorus calamus (Araceae). Econ. Bot. 1994, 48, 397-412. [CrossRef]

61. Krochmal, A.; Krochmal, C. A Guide to the Medicinal Plants of the United States; Quadrangle/The New York Times Book Co: New York, NY, USA, 1975.

62. El'Yashevych, O.H.; Cholii, R. Some means of treatment in the folk medicine of L'Vov. Farmatsevtychnyi Zhurnal 1972, 27, 78 .

63. Barton, B.H.; Castle, T. The British Flora Medica; Chatto and Windus: Piccadilly, London, UK, 1877.

64. Mokkhasamit, M.; Ngarmwathana, W.; Sawasdimongkol, K.; Permphiphat, U. Pharmacological evaluation of Thai medicinal plants. (Continued). J. Med. Assoc. Thail. 1971, 54, 490-504.

65. Harris, B.C. The Complete Herbal; Barre Publishers: Barre, MA, USA, 1972.

66. Lindley, J. Flora Medica; Paternoster-Row: London, UK, 1838.

67. Caius, J.F. The Medicinal and Poisonous Plants of India; Scientific Publishers: Jodhpur, India, 1986.

68. Clymer, R.S. Nature's Healing Agents; Dorrance and Company: Philadelphia, PA, USA, 1963.

69. Manfred, L. Siete Mil Recetas Botanicas a Base de Mil Trescientas Plantas; Edit Kier: Buenos Aires, Argentina, 1947.

70. Dobelis, I.N. Magic and Medicine of Plants; The Reader's Digest Association, Inc.: Pleasantville, New York, NY, USA, 1986.

71. Kumar, H.; Song, S.Y.; More, S.V.; Kang, S.M.; Kim, B.Y. Traditional Korean East Asian Medicines and Herbal Formulations for Cognitive Impairment. Molecules 2013, 18, 14670-14693. [CrossRef]

72. Napagoda, M.T.; Sundarapperuma, T.; Fonseka, D.; Amarasiri, S.; Gunaratna, P. Traditional Uses of Medicinal Plants in Polonnaruwa District in North Central Province of Sri Lanka. Scientifica 2019, 2019, 1-12. [CrossRef]

73. Chaudhury, S.S.; Gautam, S.K.; Handa, K.L. Composition of calamus oil from calamus roots growing in Jammu and Kashmir. Indian J. Pharm. Sci. 1957, 19, 183-186.

74. Mukherjee, P.K. Quality Control of Herbal Drugs: An Approach to Evaluation of Botanicals; Business Horizons: New Delhi, India, 2002; pp. 692-694.

75. Soledade, M.; Pedras, C.; Zheng, Q. The Chemistry of Arabidopsis thaliana. Comp. Nat. Prod. 2010, 3, 1297-1315.

76. Sharma, J.D.; Dandiya, P.C.; Baxter, R.M.; Kandel, S.I. Pharmacodynamical effects of asarone and $\beta$-asarone. Nature 1961, 192, 1299-1300. [CrossRef]

77. Sharma, P.K.; Dandiya, P.C. Synthesis and some pharmacological actions of asarone. Indian J. Appl. Chem. 1969, 32, 236-238.

78. Nigam, M.C.; Ateeque, A.; Misra, L.N. GC-MS examination of essential oil of Acorus calamus. Indian Perfum. 1990, 34, 282-285.

79. Matejić, J.; Šarac, Z.; Ranđelović, V. Pharmacological activity of sesquiterpene lactones. Biotech. Biotechnol. Equip. 2010, 24, S95-S100. [CrossRef] 
80. Benaiges, A.; Guillén, P. Botanical Extracts. Anal. Cosmet. Prod. 2007, 345-363. [CrossRef]

81. Sparg, S.; Light, M.E.; Van Staden, J. Biological activities and distribution of plant saponins. J. Ethnopharmacol. 2007, 94, 219-243. [CrossRef]

82. Rai, R.; Siddiqui, I.R.; Singh, J. Triterpenoid Saponins from Acorus calamus. ChemInform 1998, 29, 473-476.

83. Rai, R.; Gupta, A.; Siddiqui, I.R.; Singh, J. Xanthone Glycoside from rhizome of Acorus calamus. Indian J. Chem. 1999, 38, 1143-1144.

84. Kumar, S.S.; Akram, A.S.; Ahmed, T.F.; Jaabir, M.M. Phytochemical analysis and antimicrobial activity of the ethanolic extract of Acorus calamus rhizome. Orient. J. Chem. 2010, 26, $223-227$.

85. Wu, H.S.; Li, Y.Y.; Weng, L.J.; Zhou, C.X.; He, Q.J.; Lou, Y.J. A Fraction of Acorus calamus L. extract devoid of $\beta$-asarone Enhances adipocyte differentiation in 3T3-L1 cells. Phytother. Res. 2007, 21, 562-564. [CrossRef]

86. Vashi, I.G.; Patel, H.C. Chemical constituents and antimicrobial activity of Acorus calamus Linn. Comp. Physiol. Ecol. 1987, 12, 49-51.

87. Weber, M.; Brändle, R. Dynamics of nitrogen-rich compounds in roots, rhizomes, and leaves of the Sweet Flag (Acorus calamus L.) at its natural site. Flora 1994, 189, 63-68. [CrossRef]

88. Asif, M.; Siddiqi, M.T.A.; Ahmad, M.U. Fatty acid and sugar composition of Acorus calamus Linn. Fette Seifen Anstrichm. 1984, 86, 24-25. [CrossRef]

89. Lee, M.H.; Chen, Y.Y.; Tsai, J.W.; Wang, S.C.; Watanabe, T.; Tsai, Y.C. Inhibitory effect of $\beta$-asarone, a component of Acorus calamus essential oil, on inhibition of adipogenesis in 3T3-L1 cells. Food Chem. 2011, 126, 1-7. [CrossRef]

90. Padalia, R.C.; Chauhan, A.; Verma, R.S.; Bisht, M.; Thul, S.; Sundaresan, V. Variability in rhizome volatile constituents of Acorus calamus L. from Western Himalaya. J. Essent. Oil Bear. Plants 2014, 17, 32-41. [CrossRef]

91. Kumar, S.N.; Aravind, S.R.; Sreelekha, T.T.; Jacob, J.; Kumar, B.D. Asarones from Acorus calamus in combination with azoles and amphotericin b: A novel synergistic combination to compete against human pathogenic candida species In-vitro. Appl. Biochem. Biotech. 2015, 175, 3683-3695. [CrossRef]

92. Srivastava, V.K.; Singh, B.M.; Negi, K.S.; Pant, K.C.; Suneja, P. Gas chromatographic examination of some aromatic plants of Uttar Pradesh hills. Indian Perfum. 1997, 41, 129-139.

93. Özcan, M.; Akgül, A.; Chalchat, J.C. Volatile constituents of the essential oil of Acorus calamus L. grown in Konya province (Turkey). J. Essent. Oil Res. 2002, 14, 366-368. [CrossRef]

94. Kim, W.J.; Hwang, K.H.; Park, D.G.; Kim, T.J.; Kim, D.W.; Choi, D.K.; Lee, K.H. Major constituents and antimicrobial activity of Korean herb Acorus calamus. Nat. Prod. Res. 2011, 25, 1278-1281. [CrossRef]

95. Patra, A.; Mitra, A.K. Constituents of Acorus calamus: Structure of acoramone. Carbon-13 NMR spectra of cis-and trans-asarone. J. Nat. Prod. 1981, 44, 668-669. [CrossRef]

96. Saxena, D.B. Phenyl indane from Acorus calamus. Phytochemistry 1986, 25, 553-555. [CrossRef]

97. Radušienè, J.; Judžentienè, A.; Pečiulytè, D.; Janulis, V. Essential oil composition and antimicrobial assay of Acorus calamus leaves from different wild populations. Plant Genet. Resour. 2007, 5, 37-44. [CrossRef]

98. Haghighi, S.R.; Asadi, M.H.; Akrami, H.; Baghizadeh, A. Anti-carcinogenic and anti-angiogenic properties of the extracts of Acorus calamus on gastric cancer cells. Avicenna J. Phytomed. 2017, 7, 145.

99. Nawamaki, K.; Kuroyanagi, M. Sesquiterpenoids from Acorus calamus as germination inhibitors. Phytochemistry 1996, 43, 1175-1182. [CrossRef]

100. Zaugg, J.; Eickmeier, E.; Ebrahimi, S.N.; Baburin, I.; Hering, S.; Hamburger, M. Positive GABAA receptor modulators from Acorus calamus and structural analysis of (+)-dioxosarcoguaiacol by 1D and 2D NMR and molecular modeling. J. Nat. Prod. 2011, 74, 1437-1443. [CrossRef] [PubMed]

101. Yamamura, S.; Iguchi, M.; Nishiyama, A.; Niwa, M.; Koyama, H.; Hirata, Y. Sesquiterpenes from Acorus calamus L. Tetrahedron 1971, 27, 5419-5431. [CrossRef]

102. Li, J.; Zhao, J.; Wang, W.; Li, L.; Zhang, L.; Zhao, X.F.; Li, S.X. New Acorane-Type Sesquiterpene from Acorus calamus L. Molecules 2017, 22, 529. [CrossRef]

103. Zhou, C.X.; Qiao, D.; Yan, Y.Y.; Wu, H.S.; Mo, J.X.; Gan, L.S. A new anti-diabetic sesquiterpenoid from Acorus calamus. Chin. Chem. Lett. 2012, 23, 1165-1168. [CrossRef]

104. Yao, X.; Ling, Y.; Guo, S.; Wu, W.; He, S.; Zhang, Q.; Zou, M.; Nandakumar, K.S.; Chen, X.; Liu, S. Tatanan A from the Acorus calamus L. root inhibited dengue virus proliferation and infections. Phytomedicine 2018, 42, 258-267. [CrossRef]

105. Prisilla, D.H.; Balamurugan, R.; Shah, H.R. Antidiabetic activity of methanol extract of Acorus calamus in STZ induced diabetic rats. Asian Pac. J. Trop. Biomed. 2012, 2, S941-S946. [CrossRef] 
106. Prashanth, D.; Ahmed, F.Z. Evaluation of hypoglycemic activity of methanolic extract of Acorus calamus (linn). roots in alloxan induced diabetes rat model. Int. J. Basic Clin. Pharmacol. 2017, 6, 2665-2670.

107. Wu, H.S.; Zhu, D.F.; Zhou, C.X.; Feng, C.R.; Lou, Y.J.; Yang, B.; He, Q.J. Insulin sensitizing activity of ethyl acetate fraction of Acorus calamus L. In-vitro and in-vivo. J. Ethnopharmacol. 2009, 123, 288-292. [CrossRef]

108. Liu, Y.X.; Si, M.M.; Lu, W.; Zhang, L.X.; Zhou, C.X.; Deng, S.L.; Wu, H.S. Effects and molecular mechanisms of the antidiabetic fraction of Acorus calamus L. on GLP-1 expression and secretion in-vivo and In-vitro. J. Ethnopharmacol. 2015, 166, 168-175. [CrossRef] [PubMed]

109. Si, M.M.; Lou, J.S.; Zhou, C.X.; Shen, J.N.; Wu, H.H.; Yang, B.; Wu, H.S. Insulin releasing and alpha-glucosidase inhibitory activity of ethyl acetate fraction of Acorus calamus In-vitro and in-vivo. J. Ethnopharmacol. 2010, 128, 154-159. [CrossRef] [PubMed]

110. Parab, R.S.; Mengi, S.A. Hypolipidemic activity of Acorus calamus L. in rats. Fitoterapia 2002, 73, 451-455. [CrossRef]

111. D'Souza, T.; Mengi, S.A.; Hassarajani, S.; Chattopadhayay, S. Efficacy study of the bioactive fraction (F-3) of Acorus calamus in hyperlipidemia. Indian J. Pharmacol. 2007, 39, 196-200.

112. Kumar, G.; Nagaraju, V.; Kulkarni, M.; Kumar, B.S.; Raju, S. Evaluation of Antihyperlipidemic Activity of Methanolic Extract of Acorus Calamus in fat diet Induced Rats. Asian J. Med. Pharm. Sci. 2016, 4, 71-76.

113. Arun, K.S.; Augustine, A. Hypolipidemic Effect of Methanol Fraction of Acorus calamus Linn. in Diet-Induced Obese Rats. In Prospects in Bioscience: Addressing the Issues; Springer, Springer Science \& Business Media: New Delhi, India, 2012; pp. 399-404.

114. Athesh, K.; Jothi, G. Pharmacological screening of anti-obesity potential of Acorus calamus linn. In high fat cafeteria diet fed obese rats. Asian J. Pharm. Clin. Res. 2017, 10, 384-390.

115. Patel, P.; Vaghasiya, J.; Thakor, A.; Jariwala, J. Antihypertensive effect of rhizome part of Acorus calamus on renal artery occlusion induced hypertension in rats. Asian Pac. J. Trop. Dis. 2012, 2, S6-S10. [CrossRef]

116. Shah, A.J.; Gilani, A.H. Blood pressure-lowering and vascular modulator effects of Acorus calamus extract are mediated through multiple pathways. J. Cardiovasc. Pharmacol. 2009, 54, 38-46. [CrossRef]

117. Sundaramahalingam, M.; Ramasundaram, S.; Rathinasamy, S.D.; Natarajan, R.P.; Somasundaram, T. Role of Acorus calamus and alpha-asarone on hippocampal dependent memory in noise stress exposed rats. Pak. J. Biol. Sci. 2013, 16, 770-778. [CrossRef]

118. Jain, D.K.; Gupta, S.; Jain, R.; Jain, N. Anti-inflammatory Activity of $80 \%$ Ethanolic Extract of Acorus calamus Linn. Leaves in Albino Rats. Res. J. Pharm. Tech. 2010, 3, 882-884.

119. Manikandan, S.; Devi, R.S. Antioxidant property of $\alpha$-asarone against noise-stress-induced changes in different regions of rat brain. Pharmacol. Res. 2005, 52, 467-474. [CrossRef] [PubMed]

120. Devi, S.A.; Ganjewala, D. Antioxidant activities of methanolic extracts of sweet-flag (Acorus calamus) leaves and rhizomes. J. Herbs Spices Med. Plants 2011, 1, 1-11. [CrossRef]

121. Acuña, U.M.; Atha, D.E.; Ma, J.; Nee, M.H.; Kennelly, E.J. Antioxidant capacities of ten edible North American plants. Phytother. Res. 2002, 16, 63-65. [CrossRef] [PubMed]

122. Palani, S.; Raja, S.; Kumar, R.P.; Parameswaran, P.; Kumar, B.S. Therapeutic efficacy of Acorus calamus on acetaminophen induced nephrotoxicity and oxidative stress in male albino rats. Acta Pharm. Sci. 2010, 52, 89-100.

123. Venkatramaniah, C.; Praba, A.M.A. Effect of Beta Asarone-The Active Principle of Acorus Calamus in Neuroprotection and Nerve Cell Regeneration on the Pyramidal Region of Hippocampus in Mesial Temporal Lobe Epileptic Rat Models. J. Neurosci. 2019, 5, 19-24.

124. Jayaraman, R.; Anitha, T.; Joshi, V.D. Analgesic and anticonvulsant effects of Acorus calamus roots in mice. Int. J. PharmTech Res. 2010, 2, 552-555.

125. Kaushik, R.; Jain, J.; Yadav, R.; Singh, L.; Gupta, D.; Gupta, A. Isolation of $\beta$-Asarone from Acorus calamus Linn. and Evaluation of its Anticonvulsant Activity using MES and PTZ Models in Mice. Pharmacol. Toxicol. Biomed. Rep. 2017, 3, 21-26. [CrossRef]

126. Chandrashekar, R.; Adake, P.; Rao, S.N. Anticonvulsant activity of ethanolic extract of Acorus calamus rhizome in swiss albino mice. J. Sci. Innov. Res. 2013, 2, 846-851.

127. Yende, S.R.; Harle, U.N.; Bore, V.V.; Bajaj, A.O.; Shroff, K.K.; Vetal, Y.D. Reversal of neurotoxicity induced cognitive impairment associated with phenytoin and phenobarbital by Acorus calamus in mice. J. Herb. Med. Toxicol. 2009, 3, 111-115.

128. Pawar, V.S.; Anup, A.; Shrikrishna, B.; Shivakumar, H. Antidepressant-like effects of Acorus calamus in forced swimming and tail suspension test in mice. Asian Pac. J. Trop. Biomed. 2011, 1, S17-S19. [CrossRef] 
129. Pushpa, V.H.; Padmaja, S.K.; Suresha, R.N.; Vaibhavi, P.S.; Kalabharathi, H.L.; Satish, A.M.; Naidu, S. Antidepressant Activity of Methanolic Extract of Acorus Calamus Leaves in Albino Mice. Int. J. Pharm. Tech. 2013, 5, 5458-5465.

130. Shashikala, G.H.; Prashanth, D.; Jyothi, C.H.; Maniyar, I.; Manjunath, H. Evaluation of antidepressant activity of aqueous extract of roots of acorus calamus in albino mice. World J. Pharm. Res. 2015, 4, 1357-1365.

131. De, A.; Singh, M.S. Acorus calamus linn. Rhizomes extract for antidepressant activity in mice model. Adv. Res. Pharm. Biol. 2013, 3, 520-525.

132. Tripathi, A.K.; Singh, R.H. Experimental evaluation of antidepressant effect of Vacha (Acorus calamus) in animal models of depression. Ayu 2010, 31, 153-158. [CrossRef] [PubMed]

133. Pandy, V.; Jose, N.; Subhash, H. CNS activity of methanol and acetone extracts of Acorus calamus leaves in mice. J. Pharmacol. Toxicol. 2009, 4, 79-86. [CrossRef]

134. Tiwari, N.; Mishra, A.; Bhatt, G.; Chaudhary, A. Isolation of Principle Active Compound of Acorus Calamus. In-vivo assessment of pharmacological activity in the treatment of neurobiological disorder (stress). J. Med. Clin. Res. 2014, 2, 2201-2212.

135. Muthuraman, A.; Singh, N. Neuroprotective effect of saponin rich extract of Acorus calamus L. in rat model of chronic constriction injury (CCI) of sciatic nerve-induced neuropathic pain. J. Ethnopharmacol. 2012, 142, 723-731. [CrossRef]

136. Muthuraman, A.; Singh, N. Attenuating effect of Acorus calamus extract in chronic constriction injury induced neuropathic pain in rats: An evidence of anti-oxidative, anti-inflammatory, neuroprotective and calcium inhibitory effects. BMC Complement. Altern. Med. 2011, 11, 1-14. [CrossRef]

137. Vengadesh Prabu, K.; George, T.; Vinoth Kumar, R.; Nancy, J.; Kalaivani, M.; Vijayapandi, P. Neuromodulatory effect of Acrous calamus leaves extract on dopaminergic system in mice. Int. J. PharmTech Res. 2009, 1, 1255-1259.

138. Hazra, R.; Guha, D. Effect of chronic administration of Acorus calamus on electrical activity and regional monoamine levels in rat brain. Biog. Amines 2003, 17, 161-170. [CrossRef]

139. Shukla, P.K.; Khanna, V.K.; Ali, M.M.; Maurya, R.; Khan, M.Y.; Srimal, R.C. Neuroprotective effect of Acorus calamus against middle cerebral artery occlusion-induced ischaemia in rat. Hum. Exp. Toxicol. 2006, 25, 187-194. [CrossRef] [PubMed]

140. Fathima, A.; Patil, H.V.; Kumar, S. Suppression of elevated reactive oxygen species by acorus calamus (vacha) a sweet flag in drosophila melanogaster under stress full conditions. Int. J. Pharm. Sci. Res. 2014, 5, 1431-1439.

141. Kumar, M.S.; Hiremath, V.S.M.A. Cardioprotective effect of Acorus calamus against doxorubicin-induced myocardial toxicity in albino Wistar rats. Indian J. Health Sci. Biomed. Res. 2016, 9, 225-234.

142. Shah, A.J.; Gilani, A.H. Bronchodilatory effect of Acorus calamus (Linn.) is mediated through multiple pathways. J. Ethnopharmacol. 2010, 131, 471-477. [CrossRef] [PubMed]

143. Thakare, M.M.; Surana, S.J. $\beta$-Asarone modulate adipokines and attenuates high fat diet-induced metabolic abnormalities in Wistar rats. Pharmacol. Res. 2016, 103, 227-235. [CrossRef] [PubMed]

144. Karthiga, T.; Venkatalakshmi, P.; Vadivel, V.; Brindha, P. In-vitro anti-obesity, antioxidant and anti-inflammatory studies on the selected medicinal plants. Int. J. Toxicol. Pharmacol. Res. 2016, 8, 332-340.

145. Singh, D.K.; Kumar, N.; Sachan, A.; Lakhani, P.; Tutu, S.; Shankar, P.; Dixit, R.K. An experimental study to see the antihypertensive effects of gymnema sylvestre and acorus calamus in wistar rats and its comparison with amlodipine. Asian J. Med. Sci. 2017, 8, 11-15. [CrossRef]

146. Tanaka, S.; Yoichi, S.; Ao, L.; Matumoto, M.; Morimoto, K.; Akimoto, N.; Zaini bin Asmawi, M. Potential immunosuppressive and anti-inflammatory activities of Malaysian medicinal plants characterized by reduced cell surface expression of cell adhesion molecules. Phytother. Res. 2001, 15, 681-686. [CrossRef]

147. Kim, H.; Han, T.H.; Lee, S.G. Anti-inflammatory activity of a water extract of Acorus calamus L. leaves on keratinocyte HaCaT cells. J. Ethnopharmacol. 2009, 122, 149-156. [CrossRef]

148. Ahmed, S.; Gul, S.; Zia-Ul-Haq, M.; Stanković, M.S. Pharmacological basis of the use of Acorus calamus L. in inflammatory diseases and underlying signal transduction pathways. Bol. Latinoam. Caribe Plantas Med. Aromát. 2014, 13, 38-46.

149. Loying, R.; Gogoi, R.; Sarma, N.; Borah, A.; Munda, S.; Pandey, S.K.; Lal, M. Chemical Compositions, In-vitro Antioxidant, Anti-microbial, Anti-inflammatory and Cytotoxic Activities of Essential Oil of Acorus calamus L. Rhizome from North-East India. J. Essent. Oil Bear. Plants 2019, 22, 1299-1312. [CrossRef] 
150. Bahukhandi, A.; Rawat, S.; Bhatt, I.D.; Rawal, R.S. Influence of solvent types and source of collection on total phenolic content and antioxidant activities of Acorus calamus L. Natl. Acad. Sci. Lett. 2013, 36, 93-99. [CrossRef]

151. Manju, S.; Chandran, R.P.; Shaji, P.K.; Nair, G.A. In-vitro free radical scavenging potential of Acorus Calamus L. rhizome from Kuttanad Wetlands, Kerala, India. Int. J. Pharm. Pharm. Sci. 2013, 5, 376-380.

152. Barua, C.C.; Sen, S.; Das, A.S.; Talukdar, A.; Hazarika, N.J.; Barua, A.G.; Barua, I. A comparative study of the In-vitro antioxidant property of different extracts of Acorus calamus Linn. J. Nat. Prod. Plant Resour. 2014, 4, 8-18.

153. Elayaraja, A.; Vijayalakshmi, M.; Devalarao, G. In-vitro free radical scavenging activity of various root and rhizome extracts of Acorus calamus Linn. Int. J. Pharm. Biol. Sci. 2010, 1, 301-304.

154. Govindarajan, R.; Agnihotri, A.K.; Khatoon, S.; Rawat, A.K.S.; Mehrotra, S. Pharmacognostical evaluation of an antioxidant plant-Acorus calamus Linn. Nat. Prod. Sci. 2003, 9, 264-269.

155. Sujitha, R.; Bhimba, B.V.; Sindhu, M.S.; Arumugham, P. Phytochemical Evaluation and Antioxidant Activity of Nelumbo nucifera, Acorus calamus and Piper longum. Int. J. Pharm. Chem. Sci. 2013, 2, 1573-1578.

156. Shukla, R.; Singh, P.; Prakash, B.; Dubey, N.K. Efficacy of Acorus calamus L. essential oil as a safe plant-based antioxidant, A flatoxin B 1 suppressor and broad-spectrum antimicrobial against food-infesting fungi. Int. J. Food Sci. Tech. 2013, 48, 128-135. [CrossRef]

157. Ahmeda, F.; Urooja, A.; KS, R. In-vitro antioxidant and anticholinesterase activity of Acorus calamus and Nardostachys jatamansi rhizomes. J. Pharm. Res. 2009, 2, 830-833.

158. Bhat, S.D.; Ashok, B.K.; Acharya, R.N.; Ravishankar, B. Anticonvulsant activity of raw and classically processed Vacha (Acorus calamus Linn.) rhizomes. Ayu 2012, 33, 119-122. [CrossRef]

159. Patel, S.; Rajshree, N.; Shah, P. Evaluation of antidepressant activity of herbomineral formulation. Int. J. Pharm. Pharm. Sci. 2016, 8, 145-147.

160. Rauniar, G.P.; Deo, S.; Bhattacharya, S.K. Evaluation of anxiolytic activity of tensarin in mice. Kathman. Univ. Med. J. 2007, 5, 188-194.

161. Naderi, G.A.; Khalili, M.; Karimi, M.; Soltani, M. The effect of oral and intraperitoneal administration of Acorus calamus L. extract on learning and memory in male rats. J. Med. Plant 2010, 2, 46-56.

162. Vohora, S.B.; Shah, S.A.; Dandiya, P.C. Central nervous system studies on an ethanol extract of Acorus calamus rhizomes. J. Ethnopharmacol. 1990, 28, 53-62. [CrossRef]

163. Singh, B.K.; Pillai, K.K.; Kohli, K.; Haque, S.E. Isoproterenol-Induced Cardiomyopathy in Rats: Influence of Acorus calamus Linn. Cardiovasc. Toxicol. 2011, 11, 263-271. [CrossRef] [PubMed]

164. Shah, A.J.; Gilani, A.H. Aqueous-methanolic extract of sweet flag (Acorus calamus) possesses cardiac depressant and endothelial-derived hyperpolarizing factor-mediated coronary vasodilator effects. J. Nat. Med. 2012, 66, 119-126. [CrossRef]

165. Hasheminejad, G.; Caldwell, J. Genotoxicity of the alkenylbenzenes $\alpha$ - and $\beta$-asarone, myristicin and elemicin as determined by the UDS assay in cultured rat hepatocytes. Food Chem. Toxicol. 1994, 32, 223-231. [CrossRef]

166. Cartus, A.T.; Schrenk, D. Metabolism of the carcinogen alpha-asarone in liver microsomes. Food Chem. Toxicol. 2016, 87, 103-112. [CrossRef]

167. Cartus, A.T.; Stegmuller, S.; Simson, N.; Wahl, A.; Neef, S.; Kelm, H.; Schrenk, D. Hepatic metabolism of carcinogenic betaasarone. Chem. Res. Toxicol. 2015, 28, 1760-1773. [CrossRef]

168. Cartus, A.T.; Schrenk, D. Metabolism of carcinogenic alpha-asarone by human cytochrome P450 enzymes. Naunyn-Schmiedeberg's Arch. Pharmacol. 2020, 393, 213-223. [CrossRef]

169. Pandit, S.; Mukherjee, P.K.; Ponnusankar, S.; Venkatesh, M.; Srikanth, N. Metabolism mediated interaction of $\alpha$-asarone and Acorus calamus with CYP3A4 and CYP2D6. Fitoterapia 2011, 82, 369-374. [CrossRef] [PubMed]

170. Muthuraman, A.; Singh, N. Acute and sub-acute oral toxicity profile of Acorus calamus (Sweet flag) in rodents. Asian Pac. J. Trop Biomed. 2012, 2, S1017-S1023. [CrossRef]

171. Areekul, S.; Sinchaisri, P.; Tigvatananon, S. Effects of Thai plant extracts on the oriental fruit fly III. Nat. Sci. 1988, 22, 160-164.

172. Shah, P.D.; Ghag, M.; Deshmukh, P.B.; Kulkarni, Y.; Joshi, S.V.; Vyas, B.A.; Shah, D.R. Toxicity study of ethanolic extract of Acorus calamus rhizome. Int. J. Green Pharm. 2012, 6, 29-35. [CrossRef]

173. Bhat, S.D.; Ashok, B.K.; Acharya, R.; Ravishankar, B. A comparative acute toxicity evaluation of raw and classically processed rhizomes of Vacha (Acorus calamus Linn.). Indian J. Nat. Prod. Resour. 2012, 3, 506-511.

174. Keller, K.; Stahl, E. Composition of the essential oil from beta-Asarone free calamus. Planta Med. 1983, 47, 71-74. [CrossRef] 
175. JECFA (Joint FAO/WHO Expert Committee on Food Additives). Monograph on -asarone. In WHO Food Additive Series No. 16; WHO Food Additives Series; JECFA, WHO Press: Geneva, Switzerland, 1981.

176. Opdyke, D.L.J. Monographs on fragrance raw materials. Food Cosmet. Toxicol. 1973, 11, 855-876. [CrossRef]

177. Jenner, P.M.; Hagan, E.C.; Taylor, J.M.; Cook, E.L.; Fitzhugh, O.G. Food flavourings and compounds of related structure I. Acute oral toxicity. Food Cosmet. Toxicol. 1964, 2, 327-343. [CrossRef]

178. Singh, A.K.; Ravishankar, B.; Sharma, P.P.; Pandaya, T. Clinical study of anti-hyperlipidaemic activity of vacha (Acorus calamus linn) w.s.r to sthaulya. Int. Ayurvedic Med. J. 2017, 5, 1-8.

179. Tajadini, H.; Saifadini, R.; Choopani, R.; Mehrabani, M.; Kamalinejad, M.; Haghdoost, A.A. Herbal medicine Davaie Loban in mild to moderate Alzheimer's disease: A 12-week randomized double-blind placebo-controlled clinical trial. Complement. Ther. Med. 2015, 23, 767-772. [CrossRef]

180. Bhattacharyya, D.; Sur, T.K.; Lyle, N.; Jana, U.; Debnath, P.K. A clinical study on the management of generalized anxiety disorder with Vaca (Acorus calamus). Indian J. Tradit. Knowl. 2011, 10, 668-671.

181. Soni1, P.; Sharma, C. A clinical study of Vachadi Churna in the management of obesity. Int. J. Ayurveda Allied Sci. 2012, 1, 179-186.

182. Kulatunga, R.D.H.; Dave, A.R.; Baghel, M.S. Clinical efficacy of Guduchyadi Medhya Rasayana on senile memory impairment. Ayu 2012, 33, 202-208. [CrossRef] [PubMed]

183. Pande, D.N.; Mishra, S.K. Vacha (Acorus Calamus) as an ayurvedic premedicant. Ayu 2009, 30, $279-283$.

184. Mishra, J.; Joshi, N.P.; Pandya, D.M. A comparative study of Shankhapushpyadi Ghana Vati and Sarpagandhadi Ghana Vati in the management of "Essential Hypertension". Ayu 2012, 33, 54-61. [CrossRef]

185. Ramu, M.G.; Senapati, H.M.; Janakiramaiah, N.; Shankara, M.R.; Chaturvedi, D.D.; Murthy, N.N. A pilot study of role of brahmyadiyoga in chronic unmada (schizophrenia). Anc. Sci. Life 1983, 2, 205-207.

186. Appaji, R.R.; Sharma, R.D.; Katiyar, G.P.; Sai, P.A. Clinical study of the Immunoglobululin Enhancing Effect of "Bala compound" on Infants. Anc. Sci. Life 2009, 28, 18-22.

187. Pawar, M.; Magdum, P. Clinical study of assessment of therapeutic potential of Vachadi ghrita, a medicated ghee formulation on healthy individual's cognition. Int. J. Pharm. Sci. Res. 2018, 9, 3408-3413.

188. Mishra, D.; Tubaki, B.R. Effect of Brahmi vati and Sarpagandha Ghana vati in management of essential hypertension-A randomized, double blind, clinical study. J. Ayurveda Integr. Med. 2019, 10, 269-276. [CrossRef]

189. Sharma, Y.; Upadhyay, A.; Sharma, Y.K.; Chaudhary, V. A randomized clinical study to evaluate the effect of Tagaradi yoga in the management of insomnia. Indian J. Tradit. Knowl. 2017, 16, S75-S80.

190. Paradkar, S.R.; Pardhi, S.N. Clinical evaluation of lekhaniya effect of vacha (acorus calamus) and musta (cyperus rotundus) in medoroga wsr to obesity: A comparative study. Res. Rev. J. Pharmacogn. 2019, 3, 1-8.

191. Mamgain, P.; Singh, R.H. Control clinical trial of the lekhaniya drug vaca (Acorus calamus) in case of ischemic heart diseases. J. Res. Ayurveda Siddha 1994, 15, 35-51.

192. Ning, B.; Zhang, Q.; Wang, N.; Deng, M.; Fang, Y. $\beta$-Asarone Regulates ER Stress and Autophagy Via Inhibition of the PERK/CHOP/Bcl-2/Beclin-1 Pathway in 6-OHDA-Induced Parkinsonian Rats. Neurochem. Res. 2019, 44, 1159-1166. [CrossRef]

193. Ning, B.; Deng, M.; Zhang, Q.; Wang, N.; Fang, Y. $\beta$-Asarone inhibits IRE1/XBP1 endoplasmic reticulum stress pathway in 6-OHDA-induced parkinsonian rats. Neurochem. Res. 2016, 41, 2097-2101. [CrossRef] [PubMed]

194. Huang, L.; Deng, M.; Zhang, S.; Fang, Y.; Li, L. Coadministration of $\beta$-asarone and levodopa increases dopamine in rat brain by accelerating transformation of levodopa: A different mechanism from M adopar. Clin. Exp. Pharmacol. Physiol. 2014, 41, 685-690. [PubMed]

195. Huang, L.; Deng, M.; He, Y.; Lu, S.; Ma, R.; Fang, Y. $\beta$-asarone and levodopa co-administration increase striatal dopamine level in 6-hydroxydopamine induced rats by modulating P-glycoprotein and tight junction proteins at the blood-brain barrier and promoting levodopa into the brain. Clin. Exp. Pharmacol. Physiol. 2016, 43, 634-643. [CrossRef]

196. Chang, W.; Teng, J. $\beta$-asarone prevents A $\beta 25$-35-induced inflammatory responses and autophagy in SH-SY5Y cells: Down expression Beclin-1, LC3B and up expression Bcl-2. Int. J. Clin. Exp. Med. 2015, 8, 20658.

197. Liu, S.J.; Yang, C.; Zhang, Y.; Su, R.Y.; Chen, J.L.; Jiao, M.M.; Quan, S.J. Neuroprotective effect of $\beta$-asarone against Alzheimer's disease: Regulation of synaptic plasticity by increased expression of SYP and GluR1. Drug Des. Dev. Ther. 2016, 10, 1461. [CrossRef]

198. Li, C.; Xing, G.; Dong, M.; Zhou, L.; Li, J.; Wang, G.; Niu, Y. Beta-asarone protection against beta-amyloid-induced neurotoxicity in PC12 cells via JNK signaling and modulation of Bcl-2 family proteins. Eur. J. Pharmacol. 2010, 635, 96-102. [CrossRef] 
199. Xue, Z.; Guo, Y.; Zhang, S.; Huang, L.; He, Y.; Fang, R.; Fang, Y. Beta-asarone attenuates amyloid beta-induced autophagy via Akt/mTOR pathway in PC12 cells. Eur. J. Pharmacol. 2014, 741, 195-204. [CrossRef]

200. Yang, Q.Q.; Xue, W.Z.; Zou, R.X.; Xu, Y.; Du, Y.; Wang, S.; Chen, X.T. $\beta$-Asarone rescues Pb-induced impairments of spatial memory and synaptogenesis in rats. PLoS ONE 2016, 11, e0167401. [CrossRef] [PubMed]

201. Guo, J.H.; Chen, Y.; Wei, G.; Nei, H.; Zhou, Y.; Cheng, S. Effects of active components of Rhizoma Acori Tatarinowii and their compatibility at different ratios on learning and memory abilities in dementia mice. Tradit. Chin. Drug Res. Clin. Pharmacol. 2012, 23, 144-147.

202. Li, J.; Li, Z.X.; Zhao, J.P.; Wang, W.; Zhao, X.F.; Xu, B.; Li, S.X. A Novel Tropoloisoquinoline Alkaloid, Neotatarine, from Acorus calamus L. Chem. Biodivers. 2017, 14, e1700201. [CrossRef] [PubMed]

203. He, X.; Cai, Q.; Li, J.; Guo, W. Involvement of brain-gut axis in treatment of cerebral infarction by $\beta$-asaron and paeonol. Neurosci. Lett. 2018, 666, 78-84. [CrossRef]

204. Gao, E.; Zhou, Z.Q.; Zou, J.; Yu, Y.; Feng, X.L.; Chen, G.D.; Gao, H. Bioactive Asarone-derived phenylpropanoids from the rhizome of Acorus tatarinowii Schott. J. Nat. Prod. 2017, 80, 2923-2929. [CrossRef]

205. Zhang, S.; Gui, X.H.; Huang, L.P.; Deng, M.Z.; Fang, R.M.; Ke, X.H.; Fang, Y.Q. Neuroprotective effects of $\beta$-asarone against 6-hydroxy dopamine-induced parkinsonism via JNK/Bcl-2/Beclin-1 pathway. Mol. Neurobiol. 2016, 53, 83-94. [CrossRef]

206. Liang, S.; Ying, S.S.; Wu, H.H.; Liu, Y.T.; Dong, P.Z.; Zhu, Y.; Xu, Y.T. A novel sesquiterpene and three new phenolic compounds from the rhizomes of Acorus tatarinowii Schott. Bioorg. Med. Chem. Lett. 2015, 25, 4214-4218. [CrossRef]

207. Xu, F.; Wu, H.; Zhang, K.; Lv, P.; Zheng, L.; Zhao, J. Pro-neurogenic effect of $\beta$-asarone on RSC96 Schwann cells in vitro. In Vitro Cell. Dev. Biol. Anim. 2016, 52, 278-286. [CrossRef]

208. Deng, M.; Huang, L.; Ning, B.; Wang, N.; Zhang, Q.; Zhu, C.; Fang, Y. $\beta$-asarone improves learning and memory and reduces Acetyl Cholinesterase and Beta-amyloid 42 levels in APP/PS1 transgenic mice by regulating Beclin-1-dependent autophagy. Brain Res. 2016, 1652, 188-194. [CrossRef]

209. Yang, Y.; Xuan, L.; Chen, H.; Dai, S.; Ji, L.; Bao, Y.; Li, C. Neuroprotective Effects and Mechanism of $\beta$-Asarone against A $\beta 1-42-I n d u c e d$ Injury in Astrocytes. Evid.-Based Complement. Altern. Med. 2017, 2017, 8516518. [CrossRef]

210. Dong, H.; Gao, Z.; Rong, H.; Jin, M.; Zhang, X. $\beta$-asarone reverses chronic unpredictable mild stress-induced depression-like behavior and promotes hippocampal neurogenesis in rats. Molecules 2014, 19, 5634-5649. [CrossRef] [PubMed]

211. Chellian, R.; Pandy, V.; Mohamed, Z. Biphasic effects of $\alpha$-asarone on immobility in the tail suspension test: Evidence for the involvement of the noradrenergic and serotonergic systems in its antidepressant-like activity. Front. Pharmacol. 2016, 7, 72. [CrossRef] [PubMed]

212. Liu, H.; Song, Z.; Liao, D.G.; Zhang, T.Y.; Liu, F.; Zhuang, K.; Lei, J.P. Anticonvulsant and sedative effects of eudesmin isolated from Acorus tatarinowii on mice and rats. Phytother. Res. 2015, 29, 996-1003. [CrossRef] [PubMed]

213. Tian, J.; Tian, Z.; Qin, S.L.; Zhao, P.Y.; Jiang, X. Anxiolytic-like effects of $\alpha$-asarone in a mouse model of chronic pain. Metab. Brain Dis. 2017, 32, 2119-2129. [CrossRef] [PubMed]

214. Miao, J.K.; Chen, Q.X.; Li, C.; Li, X.W.; Wu, X.M.; Zhang, X.P. Modulation Effects of $\alpha$-Asarone on the GABA homeostasis in the Lithium-Pilocarpine Model of Temporal Lobe Epilepsy. Pharmacology 2013, 9, $24-32$.

215. Wang, Z.J.; Levinson, S.R.; Sun, L.; Heinbockel, T. Identification of both GABAA receptors and voltage-activated $\mathrm{Na}+$ channels as molecular targets of anticonvulsant $\alpha$-asarone. Front. Pharmacol. 2014, 5, 40. [CrossRef]

216. Chen, L.; Liao, W.P. Changes of amino acid content in hippocampus of epileptic rats treated with volatile oil of Acorus tatarinowii. Zhongguo ZhongYao ZaZhi 2004, 29, 670-673.

217. Jo, M.J.; Kumar, H.; Joshi, H.P.; Choi, H.; Ko, W.K.; Kim, J.M.; Kim, K.T. Oral administration of $\alpha$-Asarone promotes functional recovery in rats with spinal cord injury. Front. Pharmacol. 2018, 9, 445. [CrossRef]

218. Lam, K.Y.; Yao, P.; Wang, H.; Duan, R.; Dong, T.T.; Tsim, K.W. Asarone from Acori Tatarinowii Rhizome prevents oxidative stress-induced cell injury in cultured astrocytes: A signaling triggered by Akt activation. PLoS ONE 2017, 12, e0179077. [CrossRef]

219. Wu, Q.D.; Yuan, D.J.; Wang, Q.W.; Wu, X.R. Effects of volatile oil of Rhizoma Acori Tatarinowii on morphology and cell viability in cultured cardiac myocytes. Zhong Yao Cai 2009, 32, 242-245.

220. Yong, H.Y.F.Y.J.; Shuying, L.Y.W. In-vitro Observation of $\beta$-asarone for Counteracting Arteriosclerosis. J. Guangzhou Univ. Tradit. Chin. Med. 2008, 3, 14. 
221. Yang, Y.X.; Chen, Y.T.; Zhou, X.J.; Hong, C.L.; Li, C.Y.; Guo, J.Y. Beta-asarone, a major component of Acorus tatarinowii Schott, attenuates focal cerebral ischemia induced by middle cerebral artery occlusion in rats. BMC Complement. Altern. Med. 2013, 13, 236. [CrossRef] [PubMed]

222. Das, B.K.; Choukimath, S.M.; Gadad, P.C. Asarone and metformin delays experimentally induced hepatocellular carcinoma in diabetic milieu. Life Sci. 2019, 230, 10-18. [CrossRef] [PubMed]

223. Lee, S.H.; Kim, K.Y.; Ryu, S.Y.; Yoon, Y.O.O.S.I.K.; Hahm, D.H.; Kang, S.A.; Lee, H.G. Asarone inhibits adipogenesis and stimulates lipolysis in 3T3-L1 adipocytes. Cell. Mol. Biol. 2010, 56, 1215-1222.

(C) 2020 by the authors. Licensee MDPI, Basel, Switzerland. This article is an open access article distributed under the terms and conditions of the Creative Commons Attribution (CC BY) license (http://creativecommons.org/licenses/by/4.0/). 